Portland State University

PDXScholar

\title{
Decadal Topographic Change in the McMurdo Dry Valleys of Antarctica: Thermokarst Subsidence, Glacier Thinning, and Transfer of Water Storage from the Cryosphere to the Hydrosphere
}

\author{
J. S. Levy
}

Colgate University

Andrew G. Fountain

Portland State University, andrew@pdx.edu

M. K. Obryk

U.S. Geological Survey Cascades Volcano Observatory

J. Telling

University of Houston

Craig Glennie

Follow this and additional works at: https://pdxscholar.library.pdx.edu/geology_fac University of Houston

Part of the Geology Commons, Glaciology Commons, and the Hydrology Commons Let us know how access to this document benefits you.

\section{Citation Details}

Levy, J. S., Fountain, A. G., Obryk, M. K., Telling, J., Glennie, C., Pettersson, R., ... \& Van Horn, D. J. (2018). Decadal topographic change in the McMurdo Dry Valleys of Antarctica: Thermokarst subsidence, glacier thinning, and transfer of water storage from the cryosphere to the hydrosphere. Geomorphology, 323, 80-97.

This Article is brought to you for free and open access. It has been accepted for inclusion in Geology Faculty Publications and Presentations by an authorized administrator of PDXScholar. Please contact us if we can make this document more accessible: pdxscholar@pdx.edu. 


\section{Authors}

J. S. Levy, Andrew G. Fountain, M. K. Obryk, J. Telling, Craig Glennie, M. Gooseff, and David J. Van Horn 


\title{
Decadal topographic change in the McMurdo Dry Valleys of Antarctica: Thermokarst subsidence, glacier thinning, and transfer of water storage from the cryosphere to the hydrosphere
}

\author{
J.S. Levy ${ }^{\text {a,* }}$, A.G. Fountain ${ }^{\text {b }}$, M.K. Obryk ${ }^{\text {c }}$, J. Telling ${ }^{\text {d }}$, C. Glennie ${ }^{\text {d }}$, R. Pettersson ${ }^{\text {e, }}$, M. Gooseff ${ }^{\text {f }}$, D.J. Van Horn ${ }^{\mathrm{g}}$ \\ a Department of Geology, Colgate University, 13 Oak Ave., Hamilton, NY 13346, USA \\ b Department of Geology, Portland State University, Portland, OR 97201, USA \\ c U.S. Geological Survey Cascades Volcano Observatory, Vancouver, WA 98683, USA \\ d National Center for Airborne Laser Mapping, Department of Civil \&' Environmental Engineering, University of Houston, Houston, TX 77004, USA \\ e Department of Earth Sciences, Uppsala University, Geocentrum, Villav. 16, 75236 Uppsala, Sweden \\ ${ }^{\mathrm{f}}$ Department of Civil, Environmental, and Architectural Engineering, University of Colorado, Boulder, CO 80303, USA \\ g Department of Biology, University of New Mexico, Albuquerque, NM 87131, USA
}

\section{A R T I C L E I N F O}

\section{Article history:}

Received 29 May 2018

Received in revised form 9 September 2018

Accepted 10 September 2018

Available online 13 September 2018

\section{Keywords:}

Antarctic

Permafrost

Glaciers

Lidar

\begin{abstract}
A B S T R A C T
Recent local-scale observations of glaciers, streams, and soil surfaces in the McMurdo Dry Valleys of Antarctica (MDV) have documented evidence for rapid ice loss, glacial thinning, and ground surface subsidence associated with melting of ground ice. To evaluate the extent, magnitude, and location of decadal-scale landscape change in the MDV, we collected airborne lidar elevation data in 2014-2015 and compared these data to a 2001-2002 airborne lidar campaign. This regional assessment of elevation change spans the recent acceleration of warming and melting observed by long-term meteorological and ecosystem response experiments, allowing us to assess the response of MDV surfaces to warming and potential thawing feedbacks. We find that locations of thermokarst subsidence are strongly associated with the presence of excess ground ice and with proximity to surface or shallow subsurface (active layer) water. Subsidence occurs across soil types and landforms, in low-lying, low-slope areas with impeded drainage and also high on steep valley walls. Glacier thinning is widespread and is associated with the growth of fine-scale roughness. Pond levels are rising in most closed-basin lakes in the MDV, across all microclimate zones. These observations highlight the continued importance of insolation-driven melting in the MDV. The regional melt pattern is consistent with an overall transition of water storage from the local cryosphere (glaciers, permafrost) to the hydrosphere (closed basin lakes and ponds as well as the Ross Sea). We interpret this regional melting pattern to reflect a transition to Arctic and alpine-style, hydrologically mediated permafrost and glacial melt.
\end{abstract}

(C) 2018 Published by Elsevier B.V.

\section{Introduction}

Changes to Earth's terrestrial cryosphere (glaciers, snow, permafrost, and ground ice) can rapidly reorganize landscapes, leading to changes in energy balance, runoff, and ecosystem functioning. These perturbations to topography drive further changes in glacial and ground ice stability, generating positive feedbacks in frozen landscapes. For example, lidar and topographic studies of glacier surfaces in Arctic and alpine regions have shown that ablation can drive sediment mobilization and enhance melting (Irvine-Fynn et al., 2011), roughening of supraglacial channels can lead to enhanced melting (Rippin et al., 2015), and steepening of exposed glacier surfaces can enhance ablation and melt at low sun angles (Mölg, 2004). Hydrological and sediment

\footnotetext{
* Corresponding author.

E-mail address: jlevy@colgate.edu (J.S. Levy).
}

mobilization feedbacks are thought to be disintegrating the terminal regions of several Antarctic glaciers (Fountain et al., 2014).

Such positive melting feedbacks are also associated with permafrost degradation, where changes in drainage, the geometry of thermokarst ponds, channel stability, and active layer thermal properties can rapidly alter the distribution of soils, ice, and carbon (Jorgenson et al., 2006; Gooseff et al., 2011; Arp et al., 2015; Kanevskiy et al., 2016; Levy and Schmidt, 2016; Strauss et al., 2016). Hydrologically mediated melting of ground ice has led to thermokarst subsidence over broad study areas containing continuous permafrost. For example, $35 \%$ of tussock tundra sites in the Eight Mile Lake, a research watershed in Alaska, have experienced water-mediated subsurface thaw and subsidence (Belshe et al., 2013) similar to widespread thawing impacts at permafrost research sites in Siberia (Czudek and Demek, 1970).

In the Arctic, mechanisms driving permafrost degradation are wellunderstood and include i) surface warming caused by warmer air 
temperatures, ii) reduction in albedo and ponding of surface waters, which is most pronounced in glacial drifts and eolian soils (Farquharson et al., 2016), and iii) land cover disturbance (e.g., Shur and Jorgenson, 2007). The magnitude and pattern of thermokarst subsidence is strongly controlled by where ground ice is abundant and subject to melt (cryolithology) (French and Shur, 2010). In addition, enhanced thermokarst erosion occurs in lower-slope watersheds where ponding occurs, implying surface slope may play a controlling role in subsidence (Farquharson et al., 2016). Finally, landscape age plays a key role in the distribution of Arctic thermokarst-enhanced thermokarst reworking is most prevalent on older landscapes (Jorgenson and Shur, 2007). Surface- and groundwater mediated permafrost thaw are hypothesized to now be occurring in the ice-free polar deserts of Antarctica (Schmidt and Levy, 2017).

In contrast to rapidly changing Arctic and alpine cryosphere landscapes, Antarctica's largest ice-sheet-free region, the McMurdo Dry Valleys (MDV) (Fig. 1), has been mostly shielded from abrupt change due continually cool, and in cases cooling, air temperatures during the 1990s to early 2000s (Doran et al., 2002a; Shindell and Schmidt, 2004). Counterintuitively, during this period, solar radiation had been increasing significantly (Fountain et al., 2014; Obryk et al., 2018). A notable summer thaw in 2001-2002 coincided with a pivot in the cooling/ brightening climate trajectory; since 2002, summer air temperatures and elevated solar flux (Fig. 2) have remained largely constant, leading

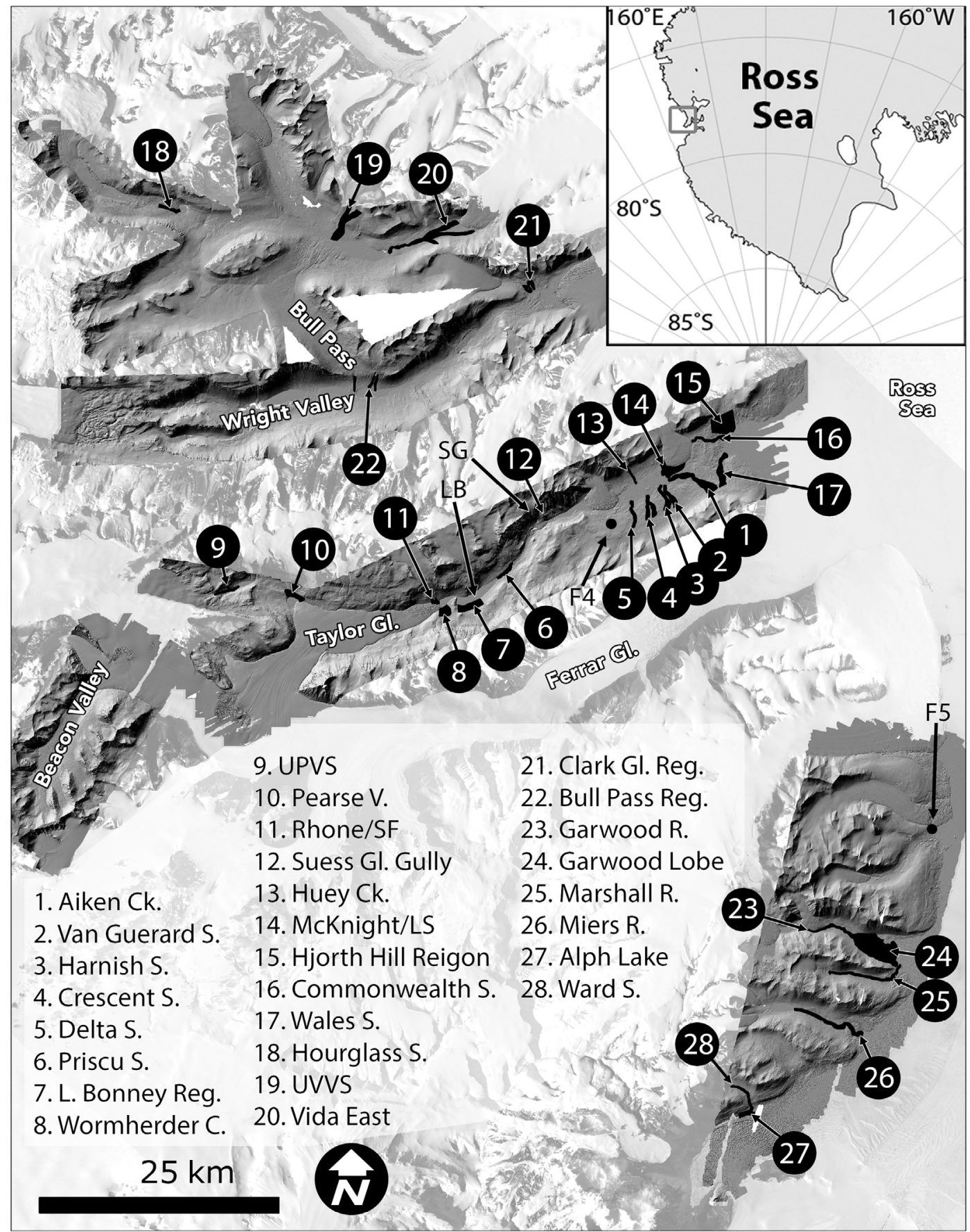

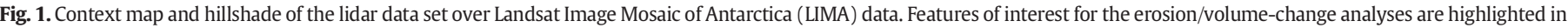

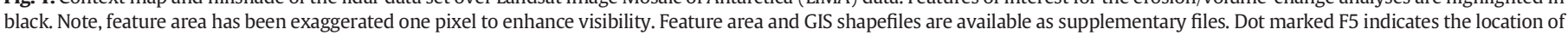
Fig. 6. Dot marked F4 indicates the location of soil roughness analyses shown in Fig. 5. LB indicates Lake Bonney. SG indicates Seuss Glacier. 

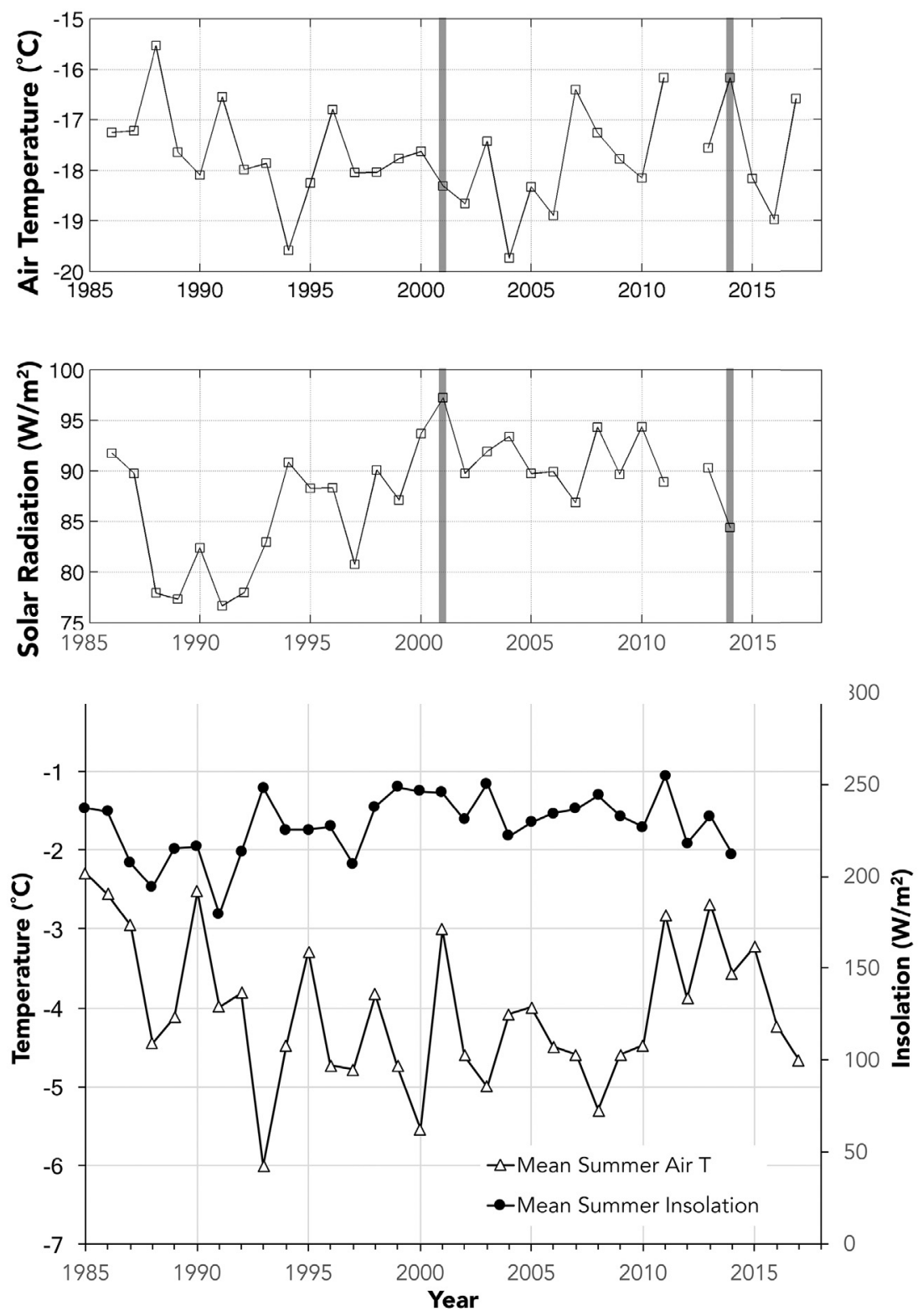

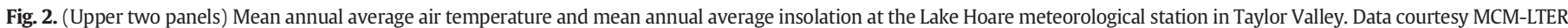

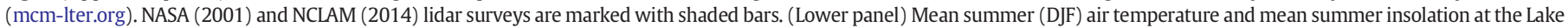

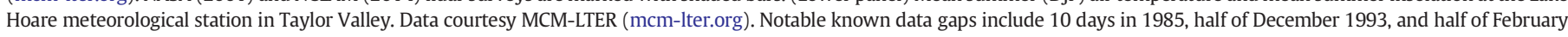
2011. Ten days of temperature data are also missing from the 2017 temperature record.

to lake ice thinning (Obryk et al., 2016a), lake level rise, and enhanced glacier runoff (Gooseff et al., 2017). These physical changes have precipitated biotic and hydrological ecosystem responses to regional warming and thawing (Fountain et al., 2016a, 2016b; Obryk et al., 2016b; Gooseff et al., 2017).

Fountain et al. (2014) identified three major classes of landscape change in the MDV that are inferred to result from this recent pulse of warming: i) disintegration and thinning of glacier surfaces, ii) formation and expansion of thermokarst slumps and ponds, and iii) the generation of stream-channel thermokarst through bank undercutting. The commonality between all these landscape changes is the interaction between sediment and ice acting as a catalyst for melting. Fountain et al. (2014) hypothesized that changes in energy budget and melting of ice altered surface topography, which led to subsequent changes to downstream hydrology and biogeochemistry. More specifically, they suggested that i) enhanced solar radiation was warming low albedo sediment, despite then-present atmospheric cooling, leading to melting of subsurface ice and dirty glacial ice; and ii) glacial meltwater flowing over the dark soils increased subsurface heat content leading to rapid thermal erosion of ice-cemented permafrost and massive subsurface ice. Fountain et al. (2014) argued that the landscape response to this insolation-driven warming of sediment mimics the expected soil warming caused by regional climate warming in the coming decades (Arblaster and Meehl, 2006; Chapman and Walsh, 2007).

Plot-scale field observations suggest that in specific locations the MDV are in the midst of rapid landscape change (Levy et al., 2013a; Dickson et al., 2015; Gooseff et al., 2016; Sudman et al., 2017). The Wright Lower Glacier (Wright Valley) has deflated several tens of meters, the Garwood River (Garwood Valley) has incised $>3 \mathrm{~m}$ into massive ice permafrost, and on Canada Glacier (Taylor Valley) $>4$ m canyons have formed (Fountain et al., 2014). Beginning in 2011-2012, thermokarst slumps appeared around streams and lakes in Taylor Valley for the first time since continuous observations of Taylor Valley began in 1993 (Fountain et al., 2014).

Here, we report on first results from an airborne lidar campaign conducted over the MDV in 2014-2015 (Fountain et al., 2017), which 
collected ground, glacier, and lake surface elevation data in order to evaluate the extent, magnitude, and location of landscape change in the MDV relative to a 2001-2002 airborne lidar campaign (Schenk et al., 2004; Csatho et al., 2005). This regional assessment of elevation change captures the decadal response of the landscape to summertime melting conditions since 2001-2002, which spans the recent increase and leveling off of solar radiation and glacier melt and runoff observed by long-term meteorological records and ecosystem response experiments (Gooseff et al., 2017). These observations allow us to provide an overview of the regional response of MDV surfaces to warming and potential thawing feedbacks through geomorphic analysis supported by field investigations involving sediment sampling and groundpenetrating radar imaging of the subsurface. In contrast to groundbased field studies, our airborne lidar intercomparison is the first time we can document the three-dimensional evolution of the MDV in close to its entirety.

\section{Regional setting}

The MDV $\left(\sim 77^{\circ} \mathrm{S}, \sim 162^{\circ} \mathrm{E}\right)$ are composed of a series of largely eastwest trending valleys that separate the East Antarctic Ice Sheet from the Ross Sea (Fig. 1). The MDV encompass a region $\sim 22,700 \mathrm{~km}^{2}$ in area, of which $\sim 4500 \mathrm{~km}^{2}$ is permafrost-affected soils and bedrock free of surface ice (Levy, 2012). The remainder of the area is covered by perennial snow packs, outlet glaciers, alpine glaciers, and perennially ice-covered lakes. A lack of vascular plants or continuous hydrological activity (e.g., rainfall, streamflow) means that the distribution of microclimates in the MDV exerts an unusually strong control on the landform evolution (Marchant and Head III, 2007). Cold temperatures and lack of an energized hydrological cycle result in a largely stable landscape, with stability increasing with elevation and distance inland. Indeed, the largest advance of the local alpine glaciers was only a few hundred meters at most and occurred 70-130 thousand years ago (Higgins et al., 2000b). At high elevations surrounding the valleys, $\sim 2000 \mathrm{~m}$, bedrock erosion rates can be as low as $<0.3 \mathrm{~m} \mathrm{Ma}^{-1}$ (Brook et al., 1995; Marchant and Head III, 2007).

With a mean annual air temperature range between $-14.8^{\circ}$ and $30.0^{\circ} \mathrm{C}$, and between 3 and $50 \mathrm{~mm}$ of annual precipitation (all of which falls as snow) (Doran et al., 2002a; Fountain et al., 1999, 2009), the MDV are a cold, polar desert (Monaghan et al., 2005). Despite these harsh climate conditions, an active, microbially dominated biological community inhabits the valleys, consisting of microbes and invertebrates (nematodes, tardigrades, rotifers, etc.) in the soils, cyanobacteria and mosses in the streams, and phytoplankton in the lakes, which has helped motivate long-term studies of this melt-limited landscape (Priscu et al., 1998; Adams et al., 2006; Cary et al., 2010).

Valley soils preserve the legacy of the interactions of seaward flowing outlet glaciers and/or landward encroachment of grounded Ross Sea Ice Sheet (RSIS). Together they form a complexly interfingered assortment of glacial tills and fluviolacustrine deposits (Stuiver et al., 1981; Denton et al., 1993; Hall and Denton, 2000; Hall et al., 2000; Higgins et al., 2000a, 2000b; Marchant et al., 2002; Ugolini and Bockheim, 2008). Below 300 m elevation, the MDV are dominated by sediments and buried ice associated with infilling of the valleys by RSIS material, mapped as Ross Sea Drift, during the last glacial maximum (Stuiver et al., 1981; Hall et al., 2000, 2015). In regions above $\sim 300 \mathrm{~m}$, old surfaces ( 1-8 MY) dominate and include the Quartermain Mountains, and the Asgard, and Olympus ranges (e.g., Marchant et al., 1993a, 1993b; Sugden et al., 1995).

The MDV soils are characterized by continuous permafrost with seasonal active layers forming on nearly all surfaces. Active layer thicknesses span 0-70 cm, with $\sim 20-30 \mathrm{~cm}$ being most common in coastal valley bottoms in Taylor Valley, Wright Valley, and Garwood Valley (Bockheim et al., 2007). Active layers $\sim 0-5 \mathrm{~cm}$ thick dominate the cold, upland, inland regions such as Beacon Valley (Marchant and Head III, 2007; Fountain et al., 2014). Active layers form over dry and ice-cemented permafrost, buried ground ice, debris-covered glaciers, and ice-cored moraines (Bockheim et al., 2007).

Permafrost is predominantly ice-cemented and ranges from icesaturated to weakly cemented, although 'dry-frozen,' ice-free, permafrost is common in the upper $\sim 1 \mathrm{~m}$ along high valley walls above icecemented permafrost (Bockheim et al., 2007). Massive buried ice (ground ice) is common and has been mapped in alpine sections of the MDV, in the Quartermain Mountains, in Victoria Valley, and in extensive ice-cored Ross Sea Drift deposits (Stuiver et al., 1981; Sugden et al., 1995; Hagedorn et al., 2010; Swanger, 2017). All three types of permafrost (dry, ice-cemented, and buried massive ice) are potentially susceptible to warming-related degradation-either directly through slumping of melt-lubricated sediments and surface ablation by melt or sublimation-driven ice removal, or indirectly, as ice-free permafrost and active layer sediments are preferentially removed by warminginduced fluvial erosion.

The thermal stability of permafrost, buried glacier ice, and other ground ice is controlled largely by regional microclimate conditions (Marchant and Head III, 2007; Hagedorn et al., 2010). Inland and highelevation areas in the upland stable zone have summer air temperatures $<-10{ }^{\circ} \mathrm{C}$ and minimal to absent active layer (Fountain et al., 2014; Marchant and Head III, 2007). As a consequence, ablation of ground ice in this zone is thought to be dominated by slow sublimation and vapor diffusion through dry overlying tills ( $\mathrm{Ng}$ et al., 2005; Hagedorn et al., 2007; Kowalewski et al., 2006, 2011a, 2011b; Lacelle et al., 2013; Marinova et al., 2013;). In contrast, coastal and low-elevation regions, Marchant and Head III's (2007) coastal thaw zone, experience mean summer air temperatures warmer than $-5{ }^{\circ} \mathrm{C}$ (Fountain et al., 2014), leading to widespread active layer thawing and refreezing of ground ice (Levy et al., 2011), as well as secular change in ground ice reservoirs as buried ice and frozen sediment melt (Healy, 1975; Campbell and Claridge, 2003; Levy et al., 2013a; Sudman et al., 2017).

\section{Methods}

\subsection{Lidar processing}

To detect landscape change in the MDV, we examined surface elevation change across the valleys by differencing an aerial lidar survey flown in the austral summer of 2001-2002 (Schenk et al., 2004; Csatho et al., 2005; Martin et al., 2005) from one flown in 2014-2015 (Fountain et al., 2017). The 2001-2002 survey used NASA's Airborne Topographic Mapper system that produced a point density in the valley bottom of at least 0.14-0.32 returns $\mathrm{m}^{-2}$ (Schenk et al., 2004; Csatho et al., 2005). The 2014-2015 survey used the Optech Titan multiwavelength airborne laser scanner (Fernandez-Diaz et al., 2016) that produced a point density of at least 2 returns $\mathrm{m}^{-2}$. The footprint (diameter) of the laser beam was $\sim 0.3 \mathrm{~m}$ for channels 1 and 2 (1550 and $1064 \mathrm{~nm}$ ) and $\sim 0.6 \mathrm{~m}$ for channel $3(532 \mathrm{~nm})$. An Optech Gemini airborne laser terrain mapper (ALTM) served as a backup to the Titan multiwavelength scanner, which uses a $1064 \mathrm{~nm}$ laser pulse at 33 to $166 \mathrm{kHz}$ and a beam divergence of 0.25 mrad. Differential kinematic trajectories for the 2014-2015 survey were derived from a total of nine UNAVCO Global Positioning System (GPS) stations recording data at a rate of $1 \mathrm{~Hz}$. The aircraft was no $>40 \mathrm{~km}$ from any station during mapping operations.

To compare the 2001 and 2014 point clouds, the original point clouds were reprocessed using identical methods, and then irregularly spaced data in the sparser 2001 data-set were interpolated using a Delaunay triangulation. Lidar data from the 2014-2015 survey were processed in three main steps: trajectory determination, point cloud production, and point cloud processing. Differential trajectories for the aircraft were derived by blending solutions from at least three GPS stations using the KARS (Kinematic and Rapid Static) software (Mader, 1996), which were then combined with orientation information collected from the onboard inertial measurement unit. Point cloud production combined laser range data with position data to produce geolocated point clouds of laser 
returns using the sensor manufacturer's proprietary software LMS for the Titan MW and DASHmap for the Gemini. Each data return was positioned in three-dimensional space by horizontal coordinates in U.S. Geological Survey Transantarctic Mountains Projection (epsg projection 3294) and vertical coordinate in meters above the World Geodetic Survey 1984 (WGS84) ellipsoid.

The 2001 interpolated mesh was subtracted from the 2014 point cloud at the resolution of the 2014 point cloud. The results were output at a gridded difference DEM with a minimum spatial resolution of 1 $\times 1 \mathrm{~m}$. Close inspection of the differenced values revealed some artifacts associated with the NASA data caused by a mounting bias that caused range errors to increase with increasing terrain slope (Martin et al., 2005). This bias of about $\pm 20 \mathrm{~cm}$ root mean square error (RMSE) and the accuracy of the 2014-2015 data of about $\pm 7 \mathrm{~cm}$ RMSE together yield an uncertainty of $\pm 21 \mathrm{~cm}$, close to our empirically derived estimate of $\pm 25 \mathrm{~cm}$. The latter was based on elimination of spurious noise in the differenced data. We applied the $\pm 25 \mathrm{~cm}$ threshold to filter the differenced data before examining elevation changes. Therefore, all landscape changes reported are larger than $\pm 25 \mathrm{~cm}$. Horizontal registration uncertainties are lower. We used an iterative closest point (ICP) comparison of $500 \mathrm{~m}$ by $500 \mathrm{~m}$ blocks from Taylor Valley in areas where horizontal movement was not expected (bedrock, valley bottoms without streams, etc.) in order to assess mismatch between point clouds. More than 50,000 points were compared, producing an average easting shift of $0.011 \mathrm{~m}$ (standard deviation $=1.63 \mathrm{~m}$ ) and an average northing shift of $-0.009 \mathrm{~m}$ (standard deviation $=1.76 \mathrm{~m}$ ). Based on the lack of a mean bias, we concluded that the data was properly horizontally registered.

Seasonal snow patches are common in MDV, and differences in patch thicknesses between lidar surveys would produce spurious elevation differences. During the 2001-2002 survey few snow patches populated the valleys as a consequence of the extremely warm air temperatures experienced that summer (Doran et al., 2008; Barrett et al., 2008). In contrast the 2014-2015 data-collection season was relatively cold and snow patches were common. To eliminate the effect of snow patch change from the differenced elevations, panchromatic Landsat 8 (Morfitt et al.,
2015) imagery at $15 \mathrm{~m}$ spatial resolution was used to identify snow patches. The imagery (LC80561162014353LGN00, 19 December 2014) was collected during the time of the 2014-2015 lidar surveys. Snowor ice-covered pixels were identified by their reflective brightness exceeding a threshold of $\geq 20 \%$ (Levy, 2012) and were removed from the difference elevation raster. Snow patches in the MDV tend to accumulate and persist in the same locations because of relatively consistent patterns of wind deposition and erosion of snow (Eveland et al., 2013). Elimination of the patches known to exist in 2014-2015 would also eliminate residual patches that may have survived in 2001-2002. Snow patches were not eliminated from either lake ice or glacier surfaces for which it can be difficult to algorithmically discern snow from underlying ice.

\subsection{Change mapping}

Landforms of interest were outlined using the 2014 DEM hillshade (Fig. 1) and were selected to explore elevation change within glacial, fluvial, lacustrine, and permafrost deposits. Landform type and location were used as mapping criteria-not elevation change (i.e., sites were not preselected for analysis based on elevation change between 2001 and 2014). Fluviolacustrine features (e.g., streams, lakes, ponds) were mapped to include a portion of the banks adjacent to the feature that may have changed. Buried ice landforms (e.g., the Garwood buried ice lobe; Stuiver et al., 1981) were mapped as close to the apparent landform boundary as possible. For pond and lake level change calculations, the entire perimeter was mapped based on smoothing visible in the lidar hillshade at the contact between the lake and the surrounding soil, and a transect of elevation across the long axis of the lake was extracted and averaged. For glacier thinning measurements, the upper elevations of the glaciers were not included due to the limited extent of the aerial surveys, restricting the differenced regions to the ablation zones. The location and extent of all selected features are included in the Supplementary data as ESRI ArcMap shapefiles.

Nearest-neighbor point differencing between the areas of interest within the 2001 and 2014 lidar point clouds was converted into a sitespecific difference raster by assigning each cell the maximum triangulated

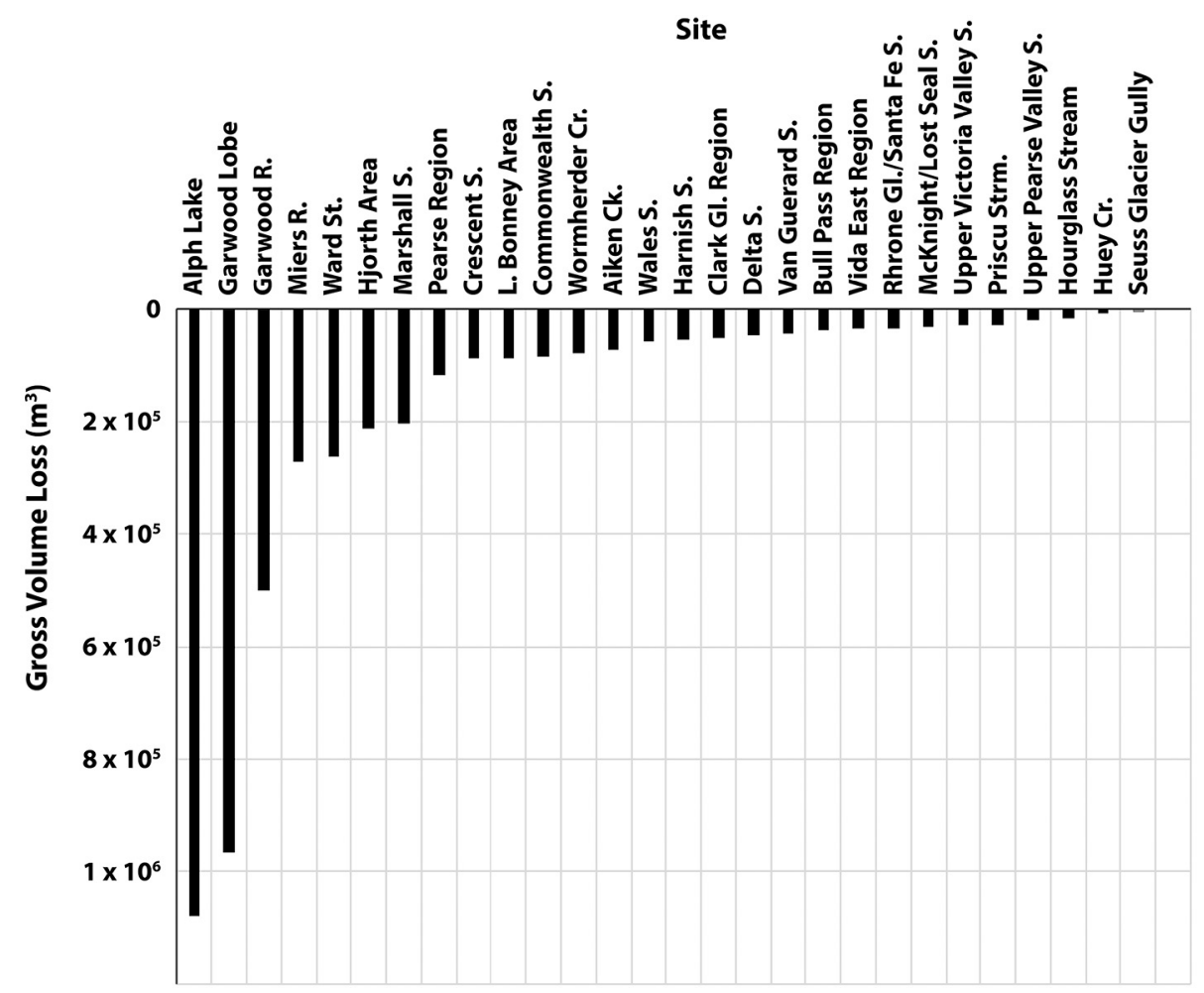

Fig. 3. Gross volume loss for the 28 features of interest. Ice loss is concentrated in the RSD (Alph, Garwood, Miers, Ward, Hjorth Marshall). 
difference value within each $1 \times 1 \mathrm{~m}$ grid cell. Note, the difference between taking the minimum point in each cell and the mean point in each cell is small, generally $<5 \%$ as there was commonly only one difference point pair in any $1 \times 1 \mathrm{~m}$ grid cell. Maximum, rather than mean subsidence was selected for this analysis because it ensures that large subsidence cells (e.g., >10 m subsidence, common in some extreme thermokarst sites) are not truncated by the matching algorithm. This approach also records aggradation, which, although not widespread in the $\mathrm{MDV}$, is the dominant landscape change at some sites. Elevation differences within each feature outline were used to generate a measure of gross volume change with each landform footprint. Raster cells were summed by landform to determine net volume change within each landform footprint, and area-normalized net elevation change was determined by dividing net volume change by feature area. Surface elevation change rate was determined by dividing area-normalized net elevation change by the 13-year time interval between lidar surveys.

To estimate changes in area and volume for the glaciers and lakes, a polygon defining the perimeter of each landform was drawn at the break in slope between the landform and the surrounding soil apparent in the 2014 lidar hillshade. The point clouds for the 2001 NASA data and 2014 NCALM data were each converted to a surface of triangular cells (TIN) within their respective perimeters. Once the two surface models were created, the area of each was calculated. The volume change is the volume between the two surfaces and a prismoidal calculation between cells was used to calculate the volume (TerraModel by Terrasolid Oy).

Surface roughness was estimated on glacier, lake ice, and soil surfaces for each of the lidar surveys by calculating the elevation difference between individual points within a circle $5 \mathrm{~m}$ in radius and the best fit plane to those points. The RMSEs from all nonoverlapping circles contained within the landscape feature were binned according to the magnitude and the relative number within each bin. These were compared to the total population within that particular landscape feature and plotted as a function of the roughness magnitude. We examined the change in surface roughness for five glaciers, four lakes, and two soil surfaces in Taylor Valley and one soil surface in each of the McKelvey and Victoria valleys. Because of the mounting bias of the NASA lidar, we restricted the assessment of roughness change to roughnesses larger than the $25 \mathrm{~cm}$ threshold, which was also applied to elevation differencing.

\subsection{Subsurface characterization}

To assess the presence or absence of massive buried ice, ground penetrating radar (GPR) surveys were implemented in 2014-2015 on surfaces from sea level to $\sim 1 \mathrm{~km}$ elevation. The surveys were collected on foot using a Malå ProEx impulse system with $200 \mathrm{MHz}$ unshielded

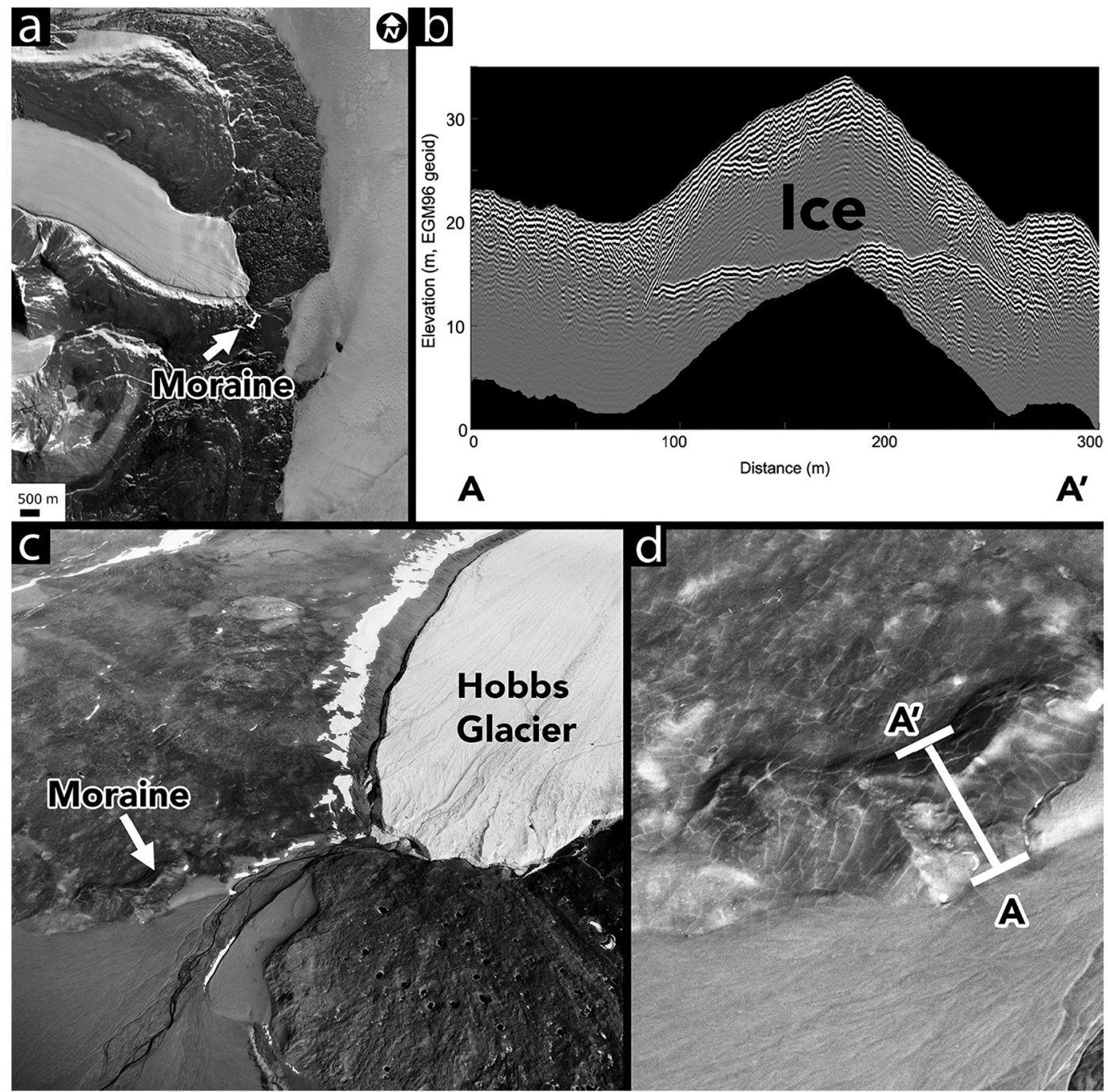

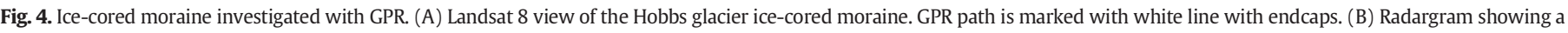

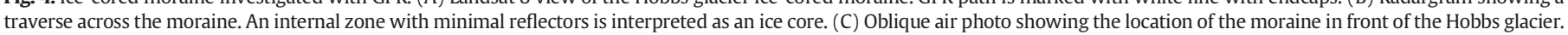
The moraine area is highlighted with enhanced contrast. (D) Zoomed in view of part (C) showing the approximate traverse of the GPR line. 
antennas. The surveys used a common-offset antenna configuration along transects with the antennas carried on a frame with minimal distance to the ground to maintain coupling with the ground. Individual GPR traces were recorded at a rate of four traces per second with each trace stacked eight times to improve the signal-to-noise ratio (Jol, 2009). Trace positions were located using a dual-frequency GPS receiver connected to the GPR and later processed using Precise-Point-Position processing (Nylen and White, 2007). Horizontal and vertical position accuracy is estimated to \pm 5 and $\pm 10 \mathrm{~cm}$ respectively. A walking speed of $\sim 2 \mathrm{~km} \mathrm{~h}^{-1}$ yields an average trace spacing of $\sim 0.2 \mathrm{~m}$ along the survey path. The vertical resolution is estimated to be $\sim 0.15 \mathrm{~m}$ for the $200 \mathrm{MHz}$ profiles based on the center frequency and sampling frequency of the radar. Survey locations were selected to test predictions (Fountain et al., 2014) on the presence or absence of ground ice (Fig. 3). The locations were based on terrain features such as moraines (possibly ice-cored-e.g., Fig. 4) and flat valley floors indicating the absence of thermokarst. The locations were also chosen to cover large elevation ranges and different slopes and slope orientations.

The post-processing of the GPR data was kept to a minimum; a Butterworth bandpass filter with cut off frequencies at 30 and $300 \mathrm{MHz}$ were used to remove noise. A background removal filter was applied to remove antenna ringing effects. Conversion of two-way travel-time of the radar wave-to-depth was done using velocities estimated from hyperbolic fitting of presumed point reflectors (Jol, 2009). The presence of massive ground ice is indicated by few internal reflectors (compared to the noisy surrounding rocky strata) and a distinct reflection at the base of the inferred ice (Fig. 4). The reflection is interpreted as the interface between the massive ground ice and the geological strata below.

\section{Geomorphic results}

Here we present observations of landscape change in the MDV based on changes derived from differencing the TIN surfaces of each lidar survey and roughness calculations (Figs. 3, 5-6). Positioning irregularities in the 2001 lidar point cloud, coupled with nonidentical spatial extents of the 2001 and 2014 point clouds resulted in an uncertainty in elevation differences of $\pm 25 \mathrm{~cm}$, as described previously. Most differences across the valleys were smaller than this threshold precluding a dataset-wide comparison of elevation change. Instead we focus on regions where changes exceeded this threshold and report on 20 glaciers, 26 ice-covered pond and lake sites, 28 soil and stream sites, and migration of 28 selected dunes.

\subsection{Glaciers}

The ablation zones of 20 glaciers in nine valleys were surveyed. These included five glaciers in Taylor Valley, five in Wright Valley, five in the Garwood, Marshall, and Miers valleys, two in McKelvey Valley, and one in each of the Barwick, Beacon, and Victoria valleys (Table 1). Changes to snow cover are thought to be small in these locations, as lidar points are in the glacier ablation zones where snow cover is ephemeral and patchy. Instead, glacier surface change is dominated by the translation of the surficial ridge and swale topography (Telling et al., 2017). Glacier ablation zones have largely thinned over the 14-year period with mean elevation changes ranging from $-2.1 \mathrm{~m}$ at Miers Glacier in Miers Valley to $-0.28 \mathrm{~m}$ at Victoria Lower glacier. All ablation zones have thinned, most of which exceed uncertainty, except for four glaciers. For these latter glaciers the uncertainty well exceeds thickening except for Taylor Glacier, which equals its uncertainty $(+0.40 \pm 0.41 \mathrm{~m})$. All glaciers examined are relatively small alpine glaciers with the exception of Taylor, which is an outlet glacier of the East Antarctic Ice Sheet. In addition to the changes in elevation of the glaciers' ablation zones, glaciers also smoothed between 2001 and 2014 (Fig. 6).

\subsection{Lakes and ponds}

Ponds and lakes in the MDV are widespread (see Supplementary map and table) across all microclimate zones and can be broadly divided into closed and open basins based on whether they have an outlet channel. Across the MDV, most closed-basin lake/ponds of all sizes $\left(10^{2}-10^{7} \mathrm{~m}^{2}\right)$

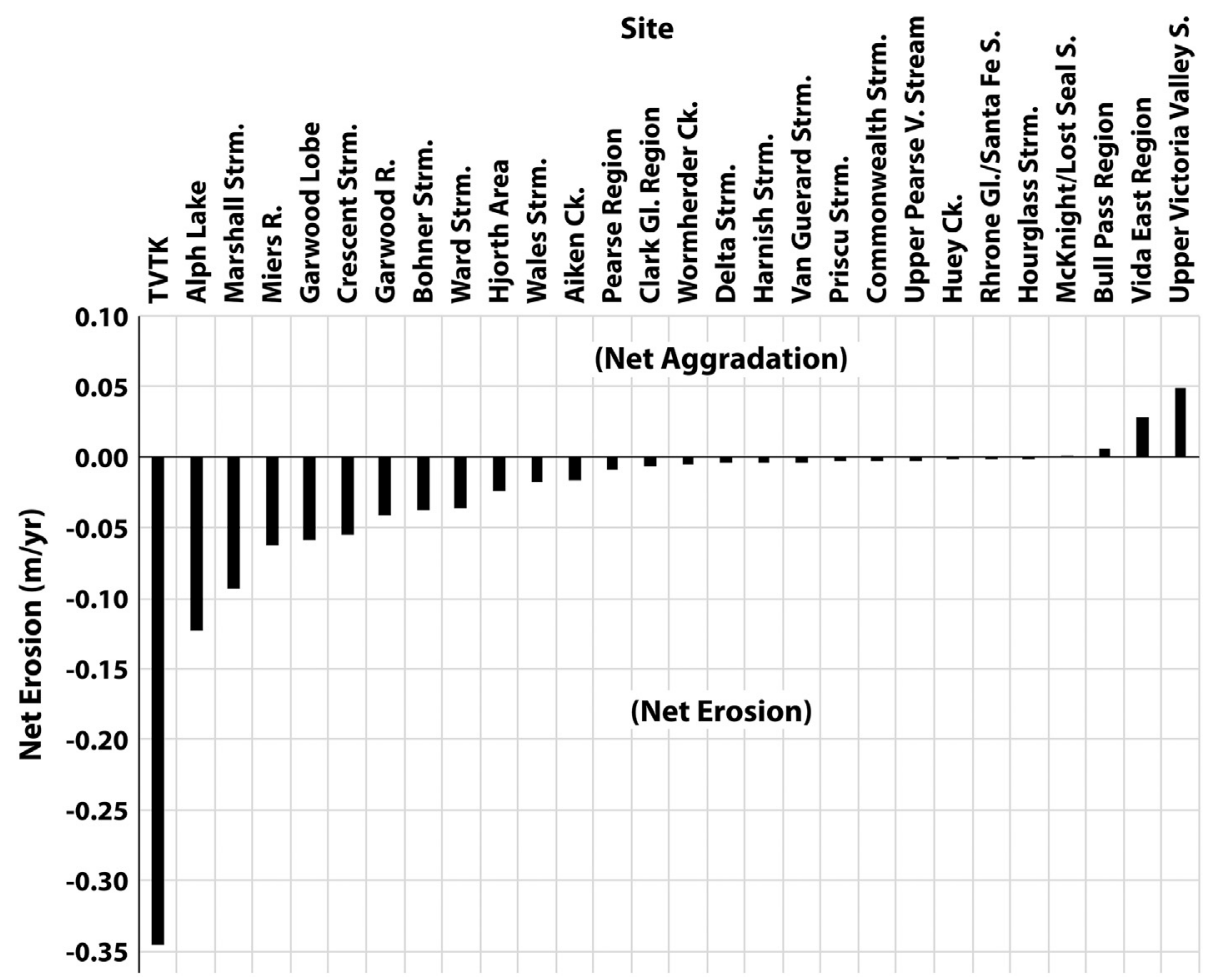

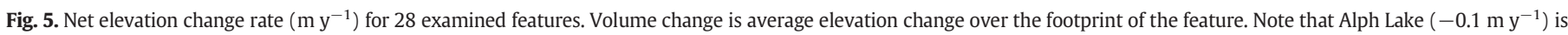
truncated on this plot. 
have risen (Fig. 7). Notably, increased levels are present across all microclimate zones, from the coastal thaw zone to the upland stable zone. For example, some closed-basin lakes $\left(\sim 10^{7} \mathrm{~m}^{2}\right)$ have risen by over $4 \mathrm{~m}$ (Fig. 7). We interpret an increase in closed-basin lake/pond levels as evidence of transfer of water reservoirs from cryosphere sources (glaciers, ground ice, and snow) to the hydrosphere (lakes and ponds).

In contrast, changing levels in open-basin lakes are not uniform and exhibit rising and falling trends (Fig. 7). Open-basin lake levels are transient as a consequence of drainage through either ice dams or topographic relief (e.g., Lake Miers, Buddha Lake) and have been observed to rise and rapidly drain when ice dams fail or the topographic spill point is reached, leading to downstream flooding (Dickson et al., 2015; Fountain et al., 2014; Levy et al., 2013a). Such lakes may appear to rise or fall depending on when in their seasonal filling and draining cycle they were surveyed, consequently open-basin lakes/ponds cannot be considered good indicators of climate-related elevation change in this study. Likewise, thermokarst ponds that are confined by glacier ice or ice-cored glacial till (e.g., Alph Lake) may be lowering because of melting of the underlying ice, even if the overlying water depth has not changed.
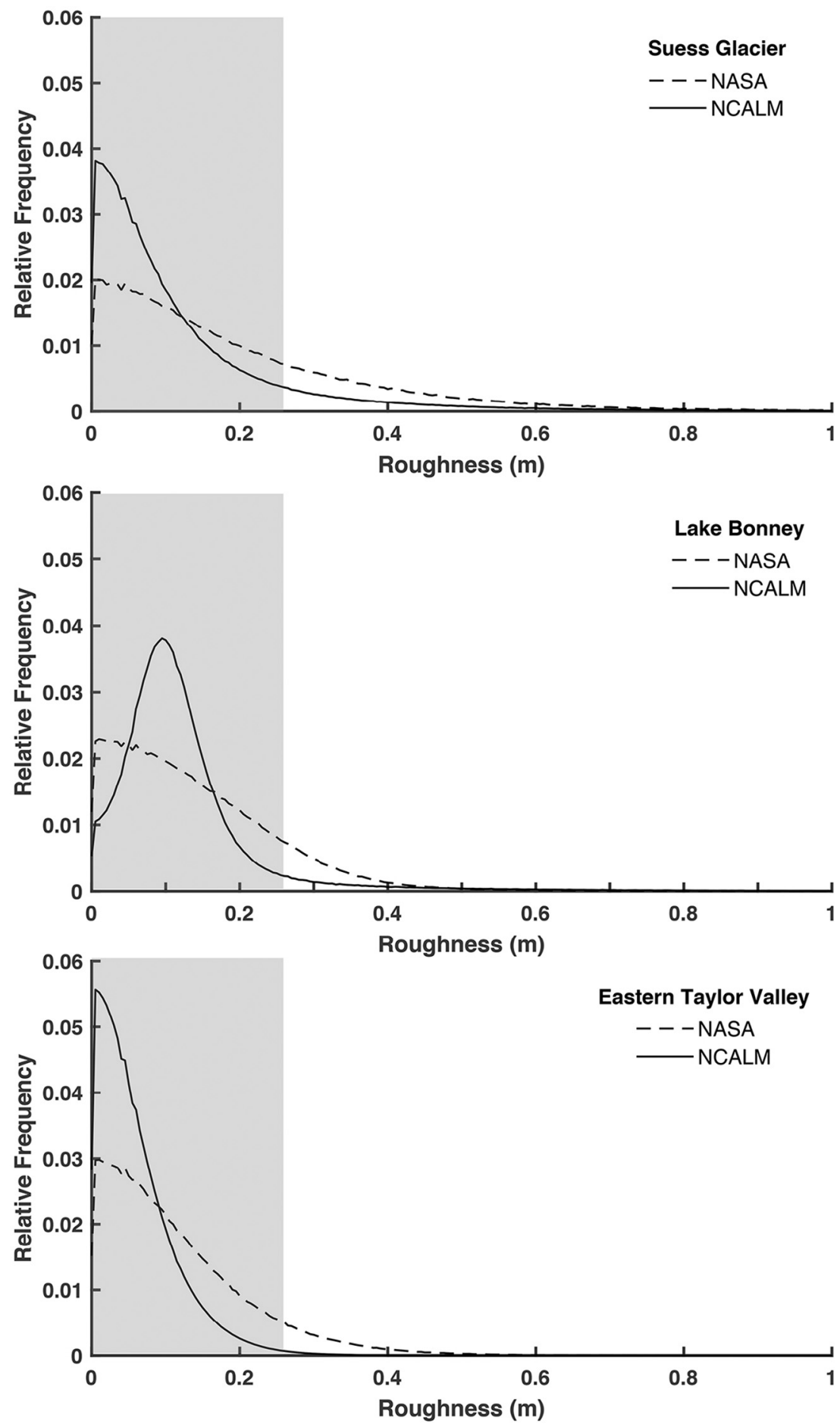

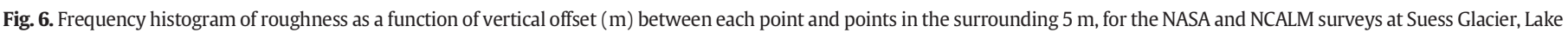

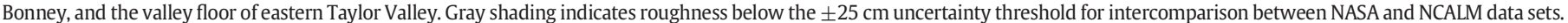




\subsection{Stream and soil sites}

We found substantial elevation changes at the 28 soil, stream, and basin locations surveyed. Each site consists of ice-cemented or ice-cored permafrost and active layer soil that has interacted with meltwater in distinct ways. The largest gross volume losses are at sites associated with icecored Ross Sea Drift (RSD): the Alph Lake basin, the Garwood lobe, the Garwood River, Miers River, Ward Stream, the Hjorth Hills area, and Marshall Valley (Fig. 3). These sites each have experienced the loss of $10^{5}$ to $10^{6} \mathrm{~m}^{3}$ of ice and soil between surveys. These sites are largely in the coastal thaw zone at elevations typically below $300 \mathrm{~m}$. Elevation change at these sites is associated with the formation of thermokarst ponds (Alph Lake, Garwood Lobe) or the deep incision by streams into buried ice deposits (Ward Stream, Garwood River, Miers and Marshall rivers, Commonwealth Stream) and the formation of thaw slumps or scarps (e.g., the Garwood Valley ice cliff, Levy et al., 2013a).

Sites exhibit a wide range of gross volume loss between surveys (Fig. 3). Alph Lake, a thermokarst pond basin with steep banks of exposed ice overlain by dark, volcanic sediments (Fig. 8), has the largest gross volume loss; while the smallest gross erosion site is Seuss Glacier Gully, a small thermoerosional gully (e.g., Fortier et al., 2007) adjacent to Seuss Glacier. Located at 288 m elevation, the Seuss Glacier Gully is not associated with valley-mouth RSD, but rather with ice from a valley-wall debris-covered glacier or gelifluction lobe. Intriguingly, when net volume change (loss minus aggradation) is normalized by landform area and time between surveys (Fig. 5), the Alph Lake basin remains the most actively melting and eroding landform; however, the Seuss Glacier Gully is then found to have the second largest areanormalized surface lowering rate (Fig. 5). This highlights the potential for ice loss and subsidence in small and large features, as well as highand low-elevation ice deposits (e.g., Swanger and Marchant, 2007).

Erosion of stream channels in the southern MDV is greatest for those flowing over ice-cored RSD, e.g., Ward, Marshall, Garwood (Figs. 3, 5, 9), and can reach tens of meters (Fig. 9). Where stream channels flow over ice-cemented permafrost only, incision is generally low; where streams flow over surfaces with pockets of massive ground ice, as is common in $\mathrm{RSD}$, erosion can reach several meters in locations where excess ice is still preserved.

Similar stream erosion patterns are observed in Taylor Valley. Surface elevation change for stream channels and banks in central Taylor Valley below 300 m elevation (Wormherder Creek, Lake Bonney area, Crescent and Delta streams, etc.) is generally small, except where patchy, massive ground ice is present that is associated with locally large volume loss (Fig. 10) (Sudman et al., 2017). In contrast, where widespread, largely intact RSD buried ice is present (e.g., Commonwealth Stream), incision can reach several meters over long reaches of the stream channel (Fig. 10).

In contrast, some study sites are actively aggrading (Fig. 5). Positive volume changes (aggradation) occur primarily on alluvial fan surfaces, such as Bull Pass area and Upper Victoria Valley stream, or in extremely sediment-rich fluvial channels, such as the proglacial McKnight/Lost Seal system that dissects a sand sheet at the toe of Commonwealth Glacier. In these sites, sediments from upslope are inferred to be undergoing deposition in the study site.

\subsection{Other landscape changes}

In terms of roughness, MDV surfaces are generally smoother (lower roughness) in 2014 than in 2001 (Fig. 6). Roughness on Seuss Glacier, Lake Bonney, and eastern Taylor Valley soil surfaces are confined to smaller magnitudes in the NCALM data-set, which could result either from smoothing of ice surfaces during widespread melting in 2001-2002 (Gooseff et al., 2017) or from the formation of enhanced roughness at small scales through channel incision. For soil surfaces, we interpret the roughness changes not to reflect changes to the soil/ permafrost surface, but rather, to reflect enhanced snow cover during the 2014 survey, which was excluded from volume change calculations (see Section 3.1).

In addition to the landscape changes described above, two other landforms warrant consideration: sand dunes in Victoria Valley (Fig. 11) and the Onyx River braidplain (Fig. 12). These surfaces provide

Table 1

Area and volume change calculations for the glacier ablation zones in the McMurdo Dry Valleys ${ }^{\mathrm{a}}$.

\begin{tabular}{|c|c|c|c|c|c|}
\hline Site name & Area $\left(m^{2}\right)$ & Volume change $\left(\mathrm{m}^{3}\right)$ & $\begin{array}{l}\text { Volume change } \\
\text { uncertainty }\left(\mathrm{m}^{3}\right)\end{array}$ & $\begin{array}{l}\text { Mean elevation } \\
\text { change }(\mathrm{m})\end{array}$ & $\begin{array}{l}\text { Mean elevation change } \\
\text { uncertainty }(\mathrm{m})\end{array}$ \\
\hline \multicolumn{6}{|l|}{ Taylor Valley sites } \\
\hline Commonwealth & $7,819,365$ & $-2,940,299$ & $\pm 1,117,314$ & -0.38 & \pm 0.38 \\
\hline Canada & $8,742,436$ & $-5,134,633$ & $\pm 1,951,161$ & -0.59 & \pm 0.38 \\
\hline Suess & $1,906,315$ & $-1,106,882$ & $\pm 365,271$ & -0.58 & \pm 0.33 \\
\hline Rhone & $1,653,101$ & $-1,189,712$ & $\pm 380,708$ & -0.72 & \pm 0.32 \\
\hline Taylor & $88,993,027$ & $35,866,247$ & $\pm 14,705,161$ & 0.40 & \pm 0.41 \\
\hline \multicolumn{6}{|l|}{ Wright Valley sites } \\
\hline Bartley & $1,610,403$ & $-1,616,094$ & $\pm 404,024$ & -1.00 & \pm 0.25 \\
\hline Meserve & $1,216,454$ & $-539,125$ & $\pm 156,346$ & -0.44 & \pm 0.29 \\
\hline Hart & $1,186,942$ & $-272,933$ & $\pm 79,151$ & -0.23 & \pm 0.29 \\
\hline Goodspeed & $2,519,629$ & 42,604 & $\pm 12,355$ & 0.02 & \pm 0.29 \\
\hline Denton & $3,237,322$ & 351,920 & $\pm 116,134$ & 0.11 & \pm 0.33 \\
\hline \multicolumn{6}{|l|}{ GMM Valleys } \\
\hline Garwood & $3,943,529$ & $-4,438,757$ & $\pm 2,485,704$ & -1.13 & \pm 0.56 \\
\hline Miers & $4,773,513$ & $-10,005,749$ & $\pm 5,202,989$ & -2.10 & \pm 0.52 \\
\hline Joyce & $1,559,768$ & $-268,387$ & $\pm 118,090$ & -1.72 & \pm 0.44 \\
\hline Adams & $2,045,894$ & $-3,253,292$ & $\pm 715,724$ & -1.59 & \pm 0.22 \\
\hline \multicolumn{6}{|c|}{ Barwick Valley sites } \\
\hline Barwick & $4,090,972$ & $-1,788,556$ & $\pm 769,079$ & -0.44 & \pm 0.43 \\
\hline \multicolumn{6}{|c|}{ Beacon Valley sites } \\
\hline Friedman & $1,928,724$ & $-447,487$ & $\pm 116,347$ & -0.23 & \pm 0.26 \\
\hline \multicolumn{6}{|c|}{ Victoria Valley sites } \\
\hline Victoria Upper & $13,617,209$ & 76,887 & $\pm 22,297$ & 0.01 & \pm 0.29 \\
\hline Victoria Lower & $5,385,597$ & $-1,502,964$ & $\pm 450,889$ & -0.28 & \pm 0.30 \\
\hline Packard & 336,000 & $-181,870$ & $\pm 49,105$ & -0.54 & \pm 0.27 \\
\hline
\end{tabular}

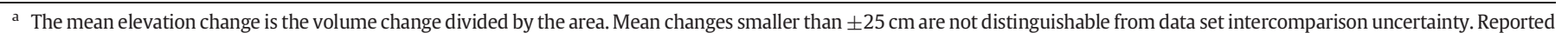
uncertainty is derived from the root mean square error of elevations from multiple control area around each glacier. 


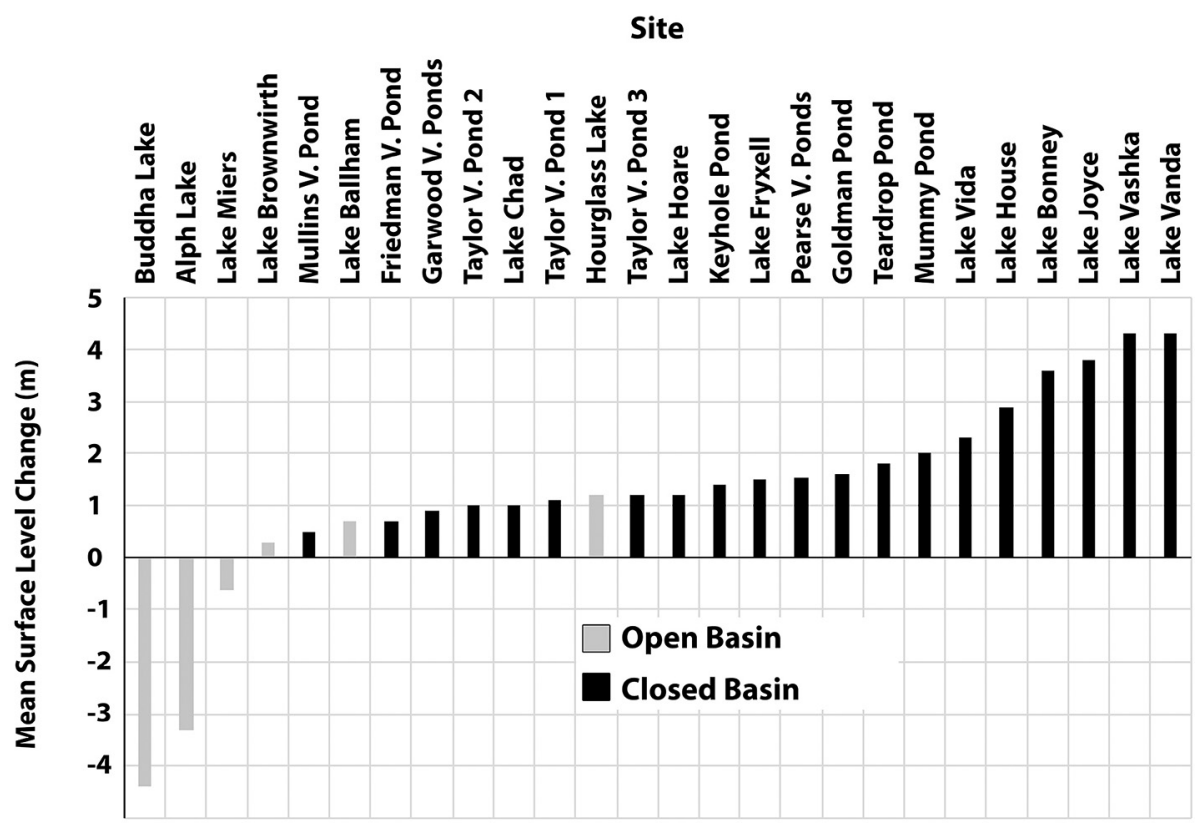

Fig. 7. Elevation changes of lakes and ponds in the McMurdo Dry Valleys between 2001 and 2002 and 2014-2015 lidar surveys.

information of landscape evolution in the MDV in which sediment transport, rather than ice loss, dominates. As with permafrost, glacier, and stream results reported above, these measurements provide a new baseline for future landform monitoring studies.

Sand saltation flux in the MDV is highest in Victoria Valley (Gillies et al., 2013), resulting in rapidly moving bedforms $\left(1.5 \mathrm{~m} \mathrm{y}^{-1}\right)$ based on the 2001/2002 lidar survey and on 1961 aerial photography (Bourke et al., 2009), which may result from enhanced sediment transport during the austral summers when sand is less cohesive as a consequence of moisture/ice ablation within the sand grains (Bristow et al., 2010). Victoria Valley, similarly to other McMurdo valleys, is subjected to bimodal wind direction with predominantly westerly winds during the austral winters and easterly winds during the austral summers (Nylen and Fountain, 2004).

Two notable dune fields are present in the Victoria Valley: whaleback dunes located along the center of the valley axis and Packard dunes adjacent to the north side of the valley (Bristow et al., 2010). The changes in both landforms are visible in lidar elevation change observations as alternating aggradation/subsidence bands resulting from migration of the bedforms. In elevation difference images (e.g., Fig. 11), bedforms migrate in the direction of negative to positive-color-coded change, showing elevation loss where the dune crest was and elevation gain where it has

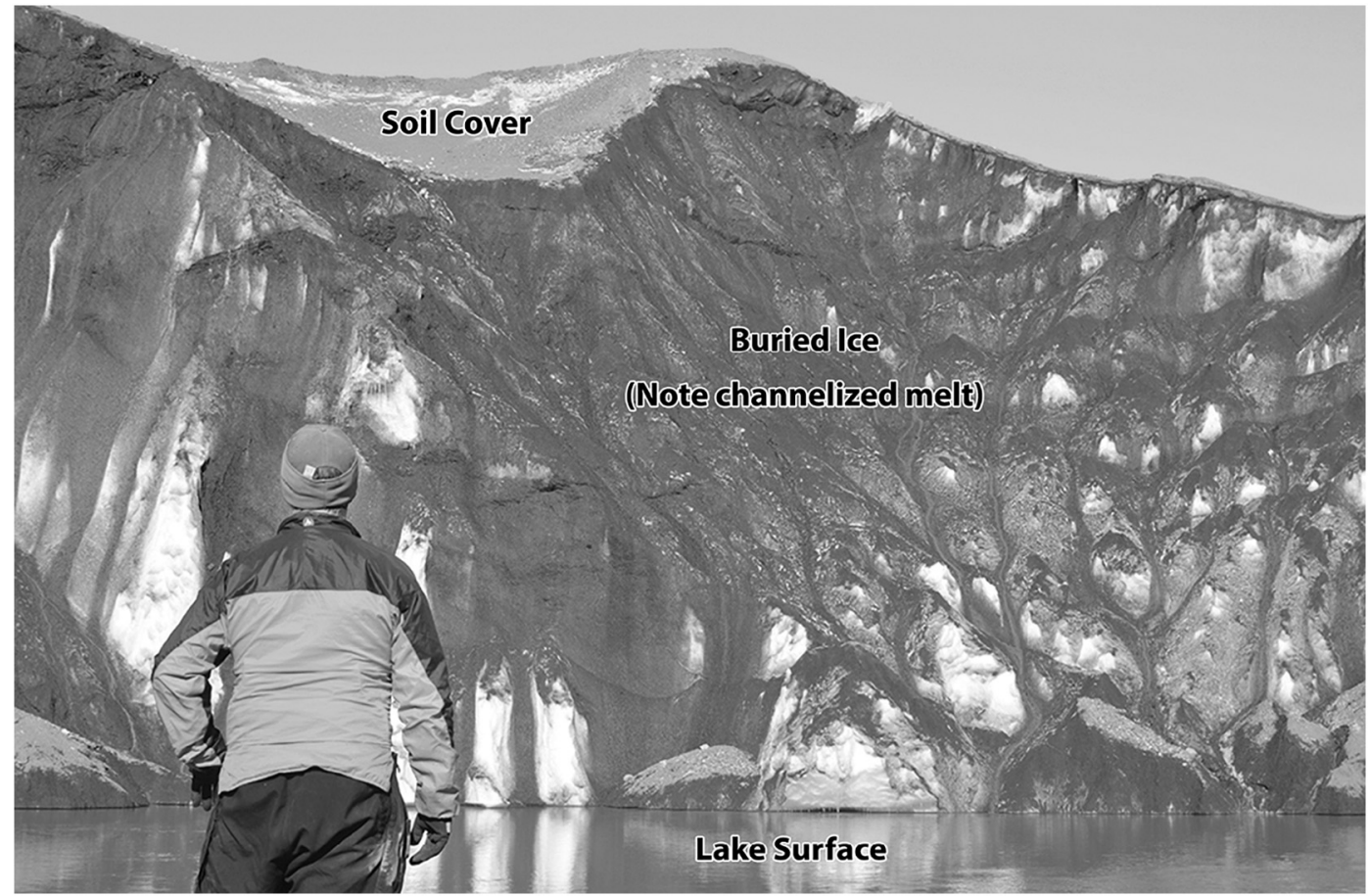

Fig. 8. Ground view of Alph Lake basin. Debris-covered (RSD) ice is melting to form a thermokarst lake at this site. Cliff face is $\sim 22 \mathrm{~m}$ tall. Photo credit: Logan Schmidt. 
migrated to. Notably, two adjacent dune fields in eastern Victoria Valley (Fig. 11) show opposite senses of migration over a $\sim 1 \mathrm{~km}$ bend in the valley resulting from a combination of topographic wind-shadowing and seasonal wind flow directions (Bristow et al., 2010). Packard dunes migrate westward due to the combination of topographic sheltering (solar radiation) and a predominant exposure to easterly winds (Bristow et al., 2010). Conversely, topographically exposed whaleback dunes, located in the center of the valley, are influenced by strong westerly katabatic and foehn winds; consequently they migrate eastward (Bristow et al., 2010). The dichotomy in migration direction of proximally located dune fields within the same valley highlights the complex surface process interactions with microclimate that can be resolved by this data-set.

The 2014-2015 lidar survey allows us to provide an update on previously quantified migration rates of the Packard dune field only (for which previous migration rate data exist). Mean distance between dune crests were determined using the following method: i) selected dune crests were outlined based on hillshade DEMs from both lidar surveys, ii) the polylines of the 2001 survey were converted to points (Feature Vertices to Points tool in ArcGIS), iii) distance between points and polylines were obtained (Near tool in ArcGIS), and iv) mean distances were calculated using the Summary Statistics tool in ArcGIS. Between the 2001-2002 and 2014-2015 lidar surveys, an average migration rate of Packard dunes was $1.4 \mathrm{~m} \mathrm{y}^{-1}$, which is consistent with the previously published migration rate of $1.5 \mathrm{~m} \mathrm{y}^{-1}$ (Bourke et al., 2009).

Finally, the Onyx River (the longest river in Antarctica) was not included in the above change detection observations owing to incomplete coverage of the river in the 2001 point cloud and notably sparse and noisy coverage near its terminus in Lake Vanda. However, where NASA and NCALM data sets overlap, details of channel morphology change can be observed (Fig. 12). The Onyx consists largely of braided and sinuous channel reaches with actively changing alternate barshowever, possible point bar growth and incipient meander formation are visible in some locations (Fig. 12). If future observations of the
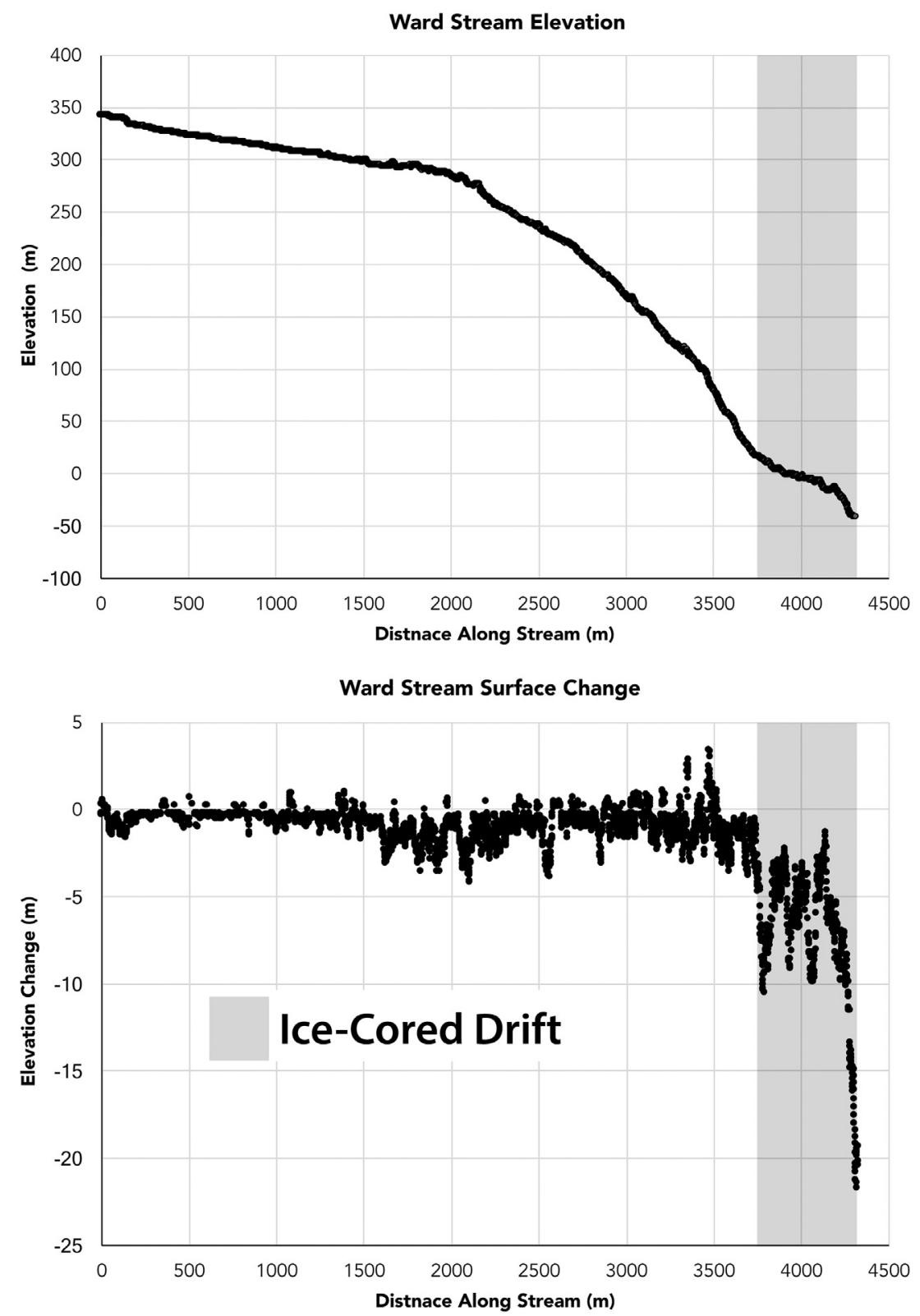

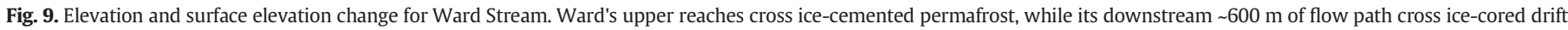

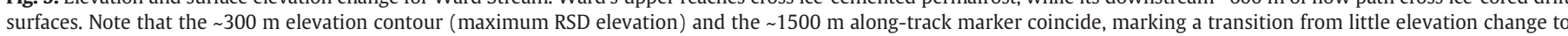
moderate. Large elevation changes occur where ice-cored drift material is fully intact and actively being eroded (gray box). 
Onyx River channel show that these reaches are evolving as meanders, it would suggest that meanders can evolve in fluvial systems in which bank cohesion is not provided by vegetation (Braudrick et al., 2009), which is absent at this site, but rather by ice-cemented permafrost.

\section{GPR results}

Buried ice masses with few to no internal reflectors are common in the MDV (Fig. 13) and are concentrated near valley bottoms. By fractional track length, $50 \%$ of ice identifications were located at or below $100 \mathrm{~m}$ elevation (representing 36\% of 2014 survey track length), and $94 \%$ were at or below 350 m elevation (on $89 \%$ of track length)-typically taken as the maximum RSD elevation (Hall et al., 2015). More buried ice appears to be present in the coastal regions, consistent with the more frequent presence of thermokarst, which is presumed to reflect buried RSIS that intruded into the valleys, most recently during the LGM. For example, divers at New Harbor, Taylor Valley documented an underwater ice wall adjacent to the shore (Stockton, 1983; Stockton et al., 1984). The GPR transects from the shore inland are initially blocked by strong signal attenuation resulting from a high salt content, after which buried ice is detected. Valley-bottom buried ice extends 1.7-1.8 km inland and thickens until the penetration limit of the GPR was reached.

Along the MDV coastline, notably rough terrain was observed associated with buried ice GPR detections, compared to smoother terrain associated with the absence of buried ice detections. Morphologically similar surfaces are present along the coast of both the central (Taylor Valley) and southern MDV (Fig. 13). Based on the field observations and GPR data, we infer and outline the extent of buried ice along the shorelines of the valleys, as shown in Fig. 13.

\section{Discussion}

Repeat lidar imaging of the MDV in 2001 and 2014 has revealed the presence of widespread changes at the landscape scale. Glaciers are thinning and smoothing, streams are incising deeply into buried ice, thermokarst ponds are forming and expanding, and a hydrologic transition from water storage in ice to water storage in streams, lakes, runoff, and groundwater is occurring. Here we discuss these changes to the MDV landscape, their potential causes, and their relationship to cryosphere landscape change observed globally.

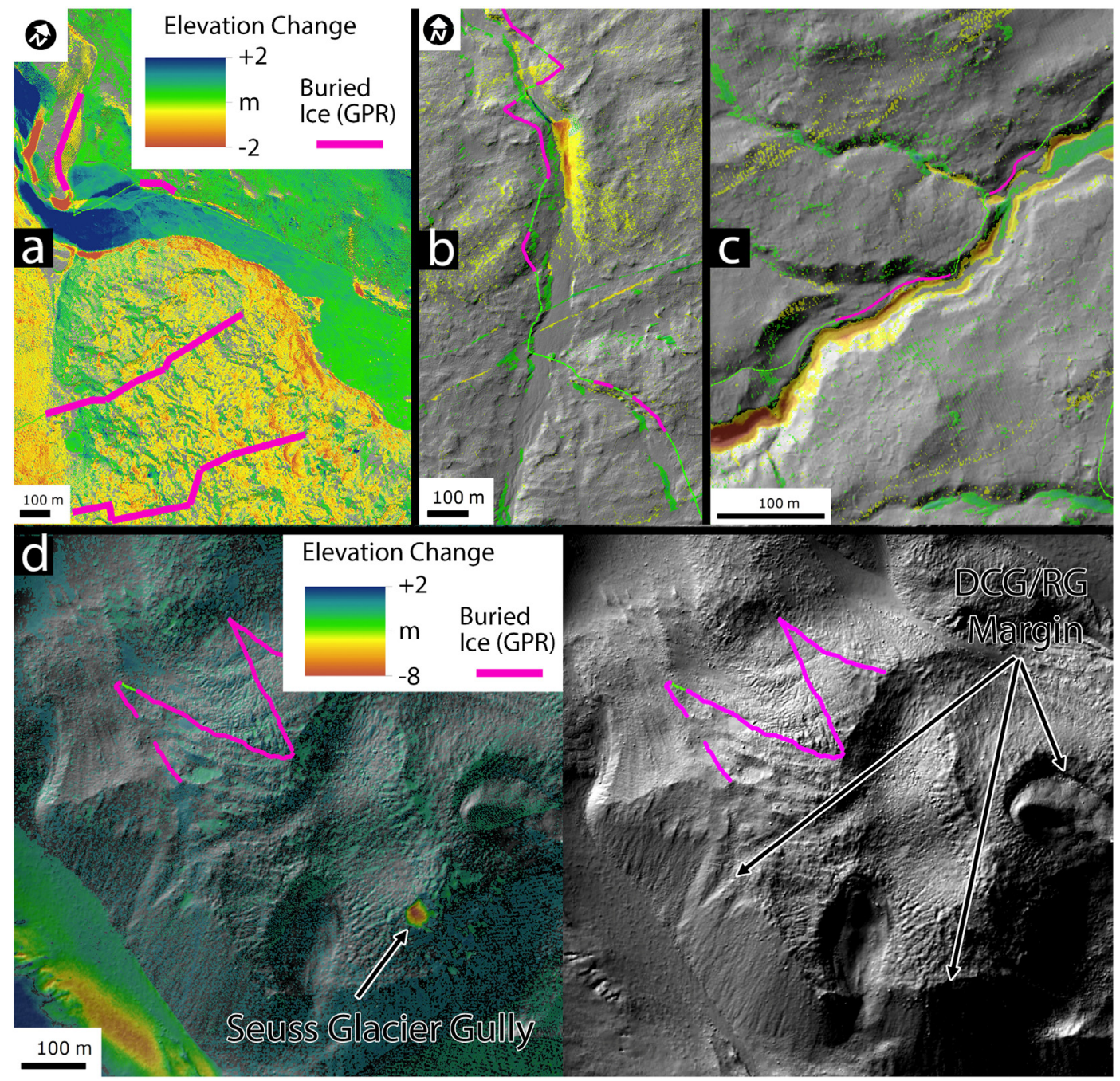

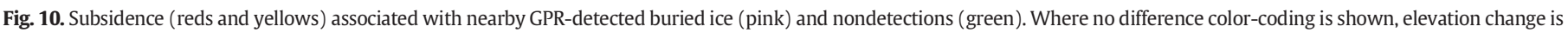

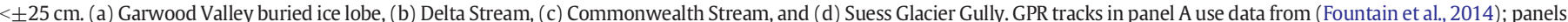

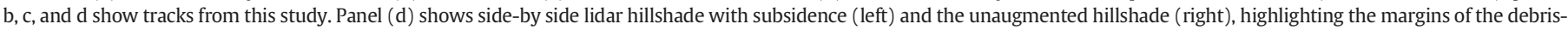

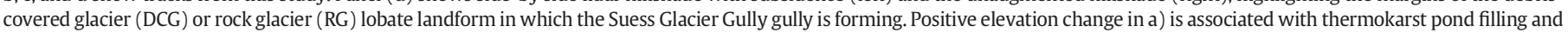
slumping deposition of sediments in steep-sided pond banks. 
With two airborne lidar campaigns, is it possible to determine whether landscape change measured by this study was: i) instantaneous (all change occurred in one episode, for example the 2001-2002 flood year, ii) episodic (change occurs in punctuated periods of activity, for example, during one or two weeks each year of the austral summer), or iii) steady state (change is incremental and nearly uniform over time)? Based on hydrological and groundbased lidar observations collected during the period between the two airborne surveys, we argue that the subsidence and pond/lake level change we observe is episodic in nature.

The MDV is still responding to the austral summer of 2001-2002 (Doran et al., 2008; Fountain et al., 2016b; Gooseff et al., 2017). While closed-basin lake level rises associated with the 2001-2002 summer and illustrated in Doran et al. (2008) are dramatic (tens of centimeters in one summer), they are part of a decades-long trend in lake level rise in the MDV noted by other authors (e.g., Castendyk et al., 2016) (Fig. SD). These multiyear observations suggest ongoing, episodic transfer of water from sources (glaciers, snow, and ground ice) to lakes and ponds, which has been occurring throughout the study interval. Likewise, landscape changes such as subsidence have been occurring at an ongoing (and in places, accelerating) rate in locations such as Garwood
Valley, with incremental ice loss in the $10^{3}-10^{4}$ of $\mathrm{m}^{3} / \mathrm{y}$ occurring every summer over a 2009 to 2012 study interval (Levy et al., 2013b) (Figs. SB, SC). Finally, interannual changes in ice loss can be observed at Alph Lake that span 1983 to 2017 (Fig. SD).

Together, we interpret these past studies and observations to indicate that melting and erosion are episodic in the MDV, occurring predominantly during summer months, but with some interannual variability. Erosion rates measured in glaciated regions are commonly reported in $\mathrm{m} / \mathrm{y}$, despite strong episodicity in these polar and alpine environments (e.g., Ganti et al., 2016). Accordingly, we report average net rates to be consistent with investigations in other glacial environments (Fig. 5), although they should be interpreted as integrations of nonuniform rates, rather than evidence of a continuous erosion process.

Glacier mass balance change stands out as an area where the 2001 and 2014 surveys cannot fully resolve change. Unfortunately, the lidar surveys were restricted to glacier ablation zones and did not cover any glacier entirely. Therefore, these changes cannot be considered glacier volume changes and cannot be compared directly to mass balance observations in the MDV (Fountain et al., 2016a). Commonwealth Glacier is the only glacier surveyed that also has a mass balance record. Over the period of time from November 2001 to November 2013, the glacier lost

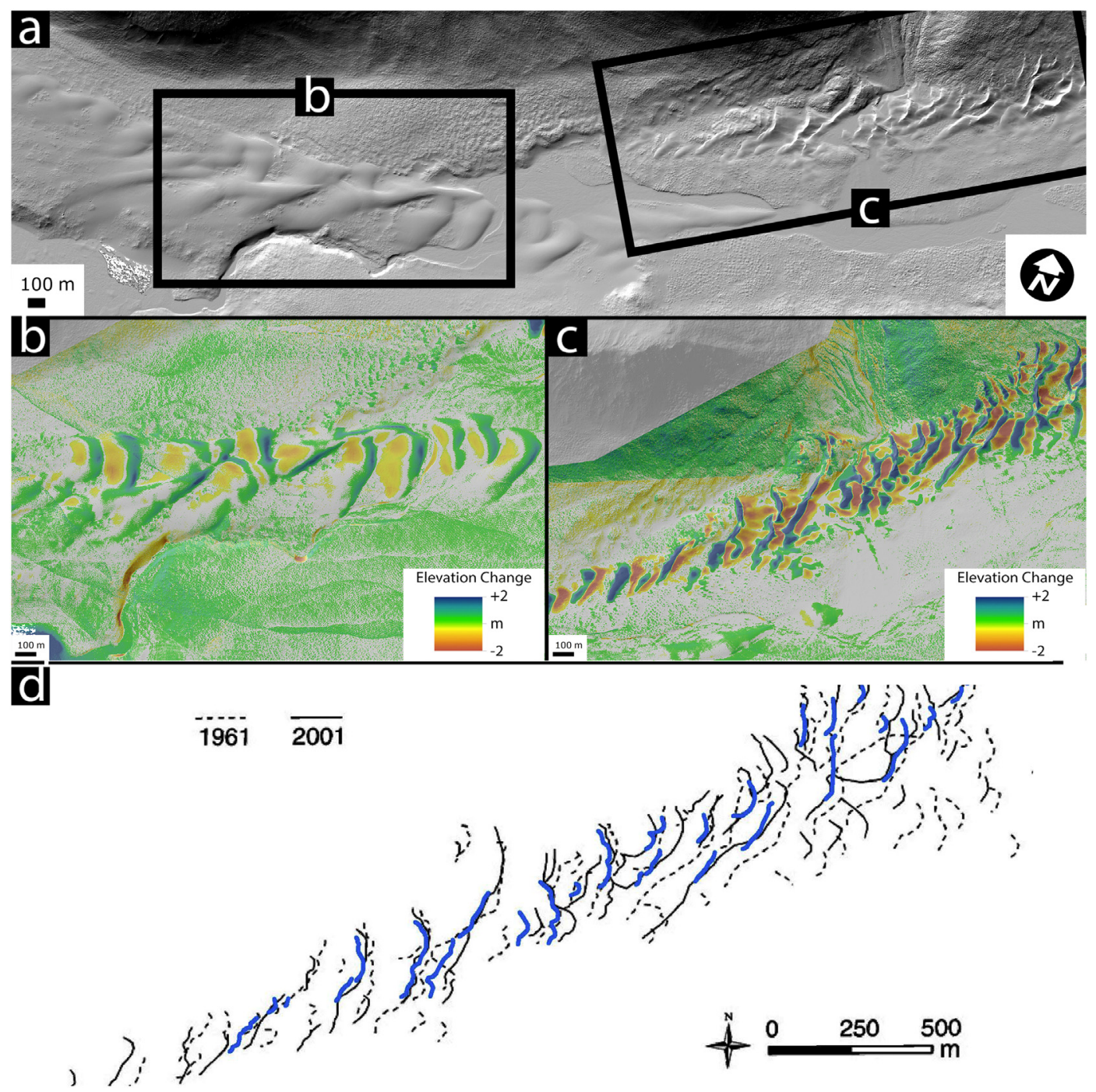

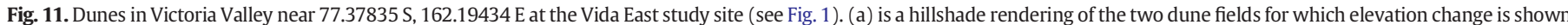

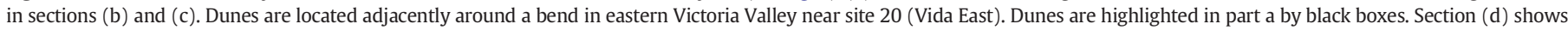
comparative dune positions from section (C), modified from Bourke et al. (2009), with new (2014) lidar-derived dune crest location shown in blue. 
a total of $-0.95 \pm 1.13 \mathrm{~m}$ water equivalent of ice that is consistent with a thinning of its ablation zone of $-0.38 \pm 0.38 \mathrm{~m}$. One glacier had a thickened ablation zone: Taylor $(+0.40 \pm 0.41 \mathrm{~m})$. Thickening ablation zones typically indicate a mass gain for a glacier. Although ablation in the lower part of Taylor Glacier has decreased slightly over the period between surveys, it is insufficient to explain the observed thickening. Moreover, the glacier has not advanced during this period. The timescale response of the glacier exceeds well over $10^{3}$ years, suggesting that the thickening could be a response to a climate perturbation in the distant past (Jóhannesson et al., 1989; Harrison et al., 2001; Roe and O'Neal, 2009; Ganti et al., 2016).

We argue that the observed smoothing of glacier and lake surfaces is real and not a result of different population of points between the two scans. As a test, the point data generated by NCALM was randomly sampled to match the number of points in the NASA data. The relative frequency of roughness was recalculated yielding no significant differences. We conjecture that the smoothing of the ice surfaces is a result of the 2001-2002 summer when air temperatures reached $4{ }^{\circ} \mathrm{C}$ for about a two-week period (Doran et al., 2008). During this period, ablation via melt was extensive, tens of centimeters on many lakes and glaciers. This ablation smoothed the icy surfaces, removing the larger roughness features. We conjecture that steep, high-angle surfaces were subject to greater total insolation, resulting in enhanced melting, and also had been darkened through capture of windblown sediment, further enhancing insolation-driven melting. The meltwater during this period filled in the depressions and froze in the latter part of the summer when the heat wave dissipated and air temperatures again cooled below freezing. Because lidar collection in 2001 largely did not capture this melt pulse (Fig. 14), we can only report on changes detectable through comparison of our two point clouds, making it impossible to precisely determine timing at finer temporal scales.

In contrast to the exposed ice surfaces of lakes and glaciers that are sensitive to episodic weather events, soil and stream bank site change appears to be largely substrate-controlled. As noted above, the largest gross volume changes in soil and streams locations are observed in areas with buried ice (e.g., Alph Lake in the Ross Sea Drift, Garwood Valley, Commonwealth Stream). The same is true for the fastest erosion rates-although it is notable that the second fastest rate measured in this study is in a small thermoerosional gully in Taylor Valley (Suess Glacier Gully). We infer that the rapid apparent subsidence rate results from the small spatial footprint of the landform coupled with the concentrated ice loss and runoff of meltwater at the site.

What connects many of the largest gross erosion sites is the presence of shallow buried ice deposits (Fig. 10). Stream thermokarst erosion has generated large topographic subsidences in ice-cored surfaces, such as the Ross Sea Drift (RSD), which fills much of the mouths of many of the MDV (e.g., Miers, Marshall, Garwood, and Taylor valleys) below $\sim 300 \mathrm{~m}$ elevation. In contrast, inland streams and those outside of RSD

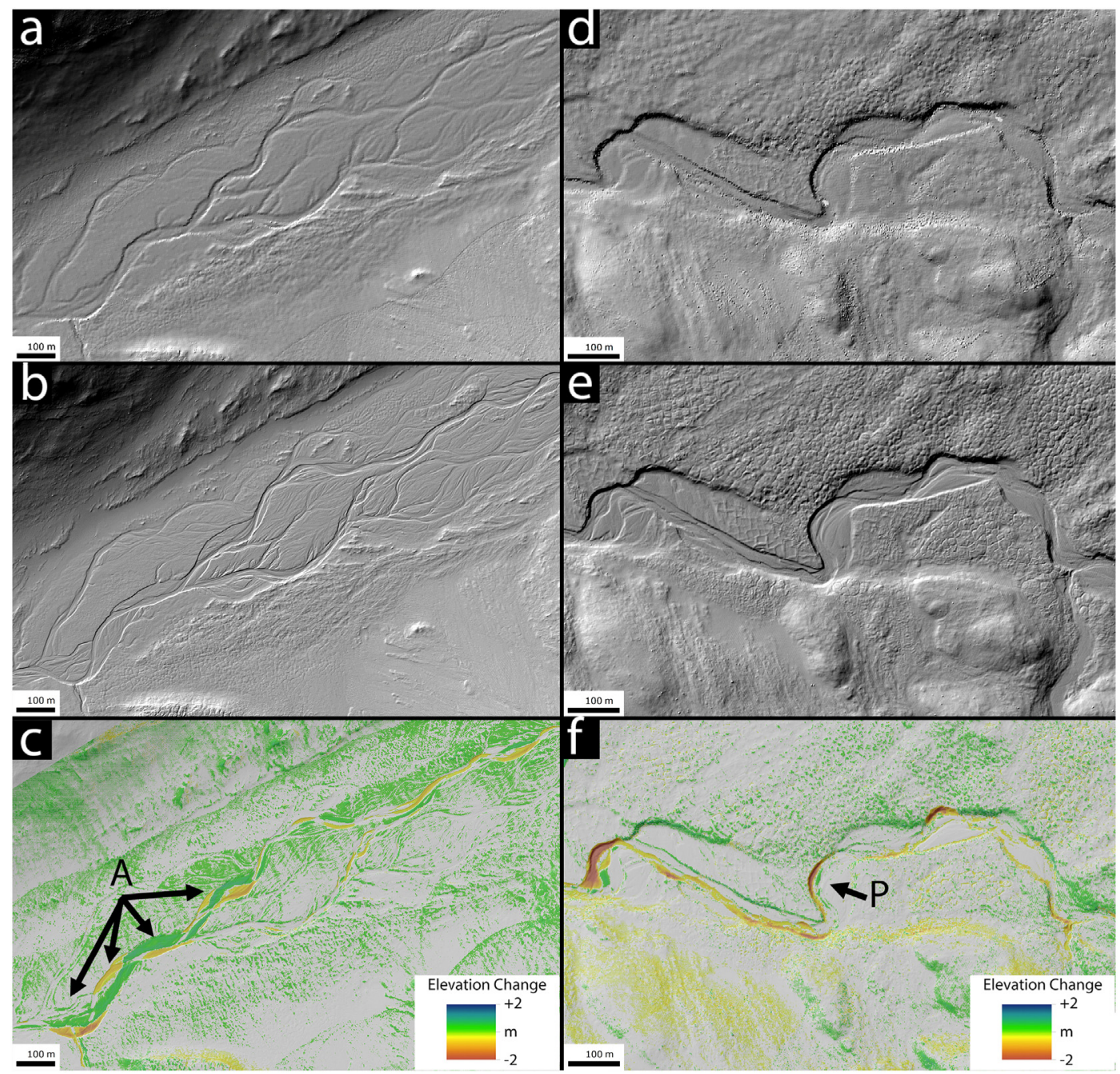

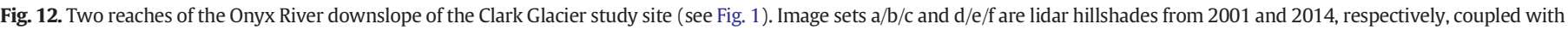

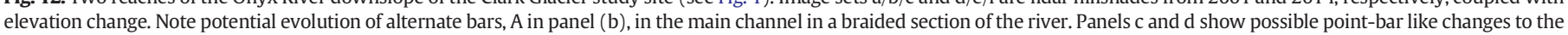
Onyx channel, P, where incision (elevation loss) has occurred on the outside bank of the river, with small amounts of deposition (bar growth) on the inner bank of a bend. 


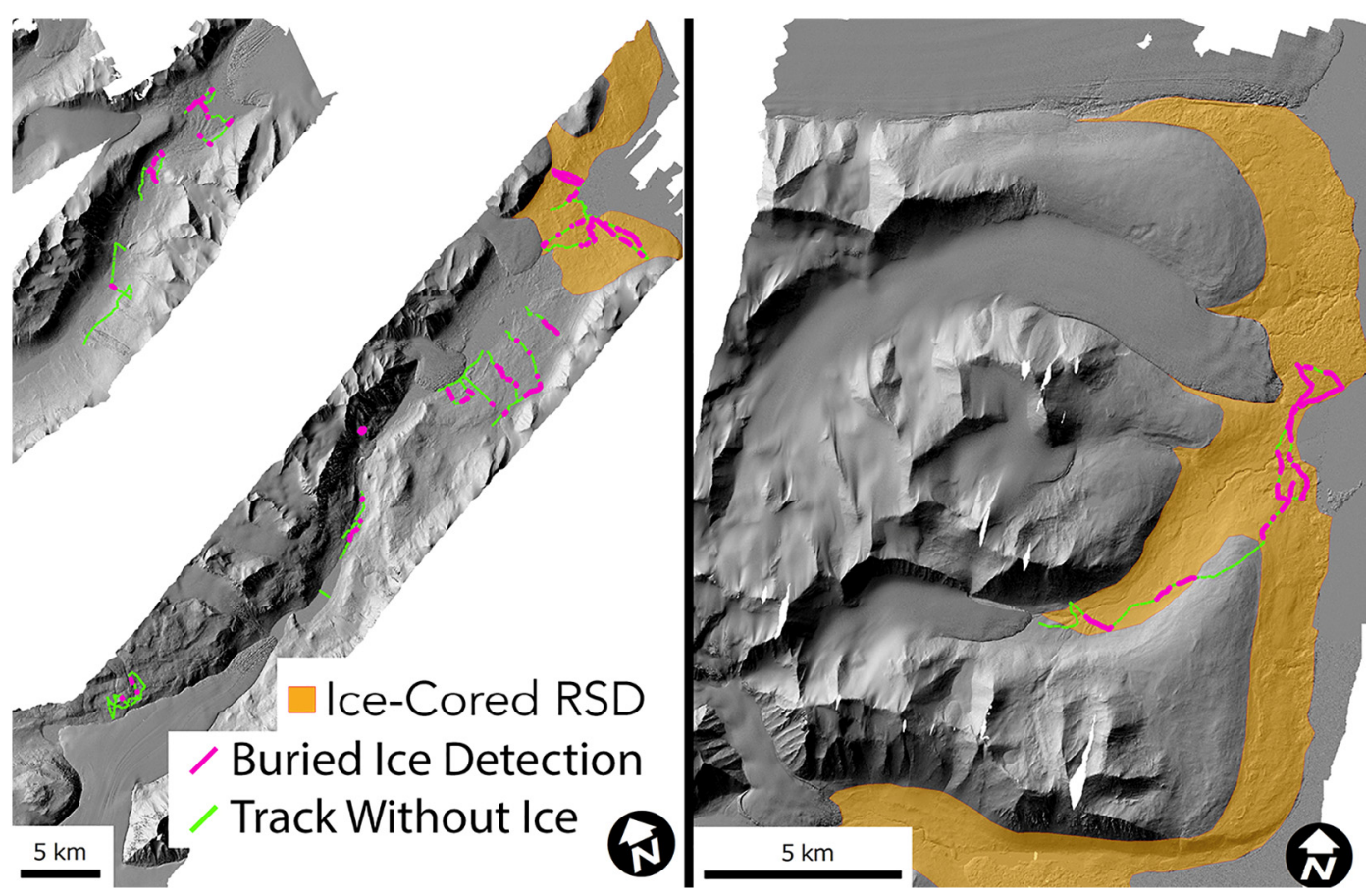

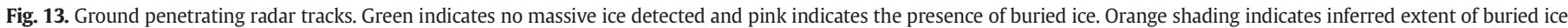
associated with the Ross Sea Drift, after Stuiver et al. (1981), modified based on field observations and GPR buried ice detections.

buried ice areas (e.g., in Wright Valley) are not incising deeply, and typically channel-average erosion rates are not more than a few $\mathrm{mm} \mathrm{y}^{-1}$. Streams in areas with high sand fluxes and little buried ice (e.g., Victoria Valley, Lost Seal) show net aggradation or sediment deposition.

Rapid and large-scale formation of thermokarst ponds and thermoerosional stream channels suggests that many portions of the MDV may be experiencing a transition to Arctic-like thermokarst morphologies. Like Farquharson et al. (2016), we see subsidence across soil types and landforms, with the primary control being the presence of massive buried ice. Unlike (Farquharson et al., 2016), we see subsidence in low-lying, low-slope areas with impeded drainage (e.g., Alph Lake, the Garwood Valley RSD lobe) and also high on steep valley walls (e.g., Suess Glacier Gully). This highlights the continued importance of insolationdriven melting in the MDV, where steep slopes with overlying or overhanging sediment are exposed to near-normal summertime illumination, leading to the potential for rapid meltout of high elevation ice deposits on steep slopes (Conovitz et al., 1998; Levy et al., 2013a).

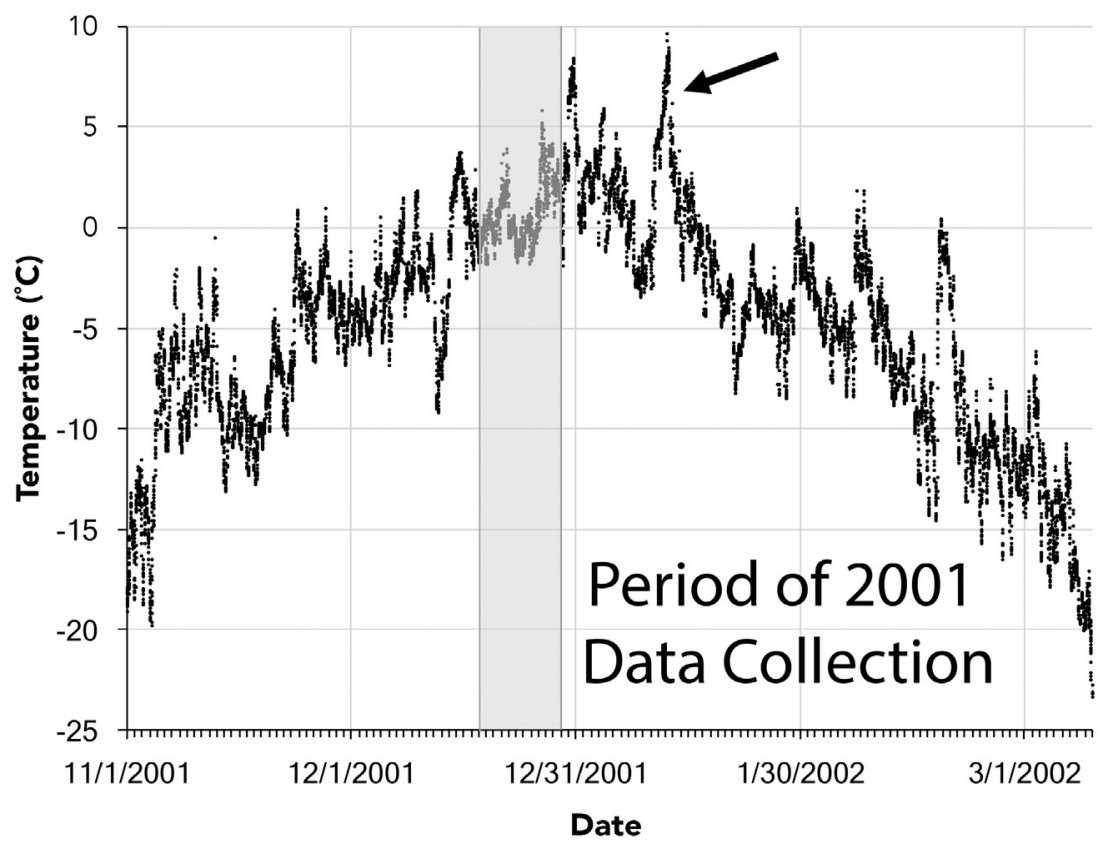

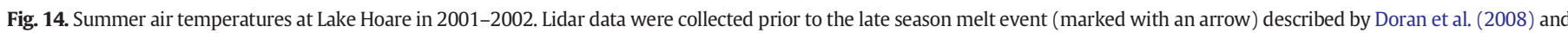
Gooseff et al. (2017). 


\subsection{Proposed mechanisms controlling regional landscape change}

We interpret these landscape changes to indicate that physical and hydrological processes associated with heat capture and transfer into the subsurface are widespread in the MDV. At the top of MDV watersheds, glaciers appear to be thinning and darkening, resulting in increased runoff into stream channels. Numerical modeling of shortwave insolation capture indicates that albedo reductions of as little as $3 \%$ are sufficient to explain observed changes in stream discharge (e.g., Hoffman et al., 2016).

Streams and groundwater in the MDV function as important pathways for heat. Where ground ice is present in MDV stream banks, we observe thermokarst erosion, bank undercutting, and release of nutrients, solutes, and sediments into streams (Gooseff et al., 2016; Sudman et al., 2017). Energy collected from glacial runoff is reaching MDV lakes and raising lake heat content (Gooseff et al., 2017).

Subsidence, sediment mobilization, and glacier/ground ice melting may be beginning to drive positive feedbacks across the MDV landscape. When sediment on glacier ablation zones reduces albedo, solar energy absorption and melt increase (Rippin et al., 2015; Hoffman et al., 2016) adding to surface fine-scale roughness, which slows the wind speed and captures more eolian sediment, further reducing albedo and heat loss to the atmosphere. Similar feedbacks exist for active layer soils. When soils become wetted, either within stream and lake margin hyporheic zones, or within water tracks or thermokarst drainage pathways, soil thermal diffusivity can rise two- to eightfold (Levy and Schmidt, 2016), leading to enhanced delivery of heat to buried ice in poorly drained soils. This exacerbates melt rates in stream hyporheic zones and in wet active layer soils. Together, we interpret these processes as potentially self-reinforcing drivers of the observed landscape changes in the MDV. Hallmarks of this change in MDV hydrogeology are i) enhanced heat transport into lakes, frozen ground, and other cold reservoirs in the MDV that have been largely unchanged since LGM time or earlier; and ii) a transition of water storage from ground ice and glaciers to lakes and ponds.

We propose that two related processes are responsible for the landscape changes observed: one trend operating at decadal timescales and another discrete event triggering a decadal geomorphic response. First, between 1991 and 2000, mean summer solar radiation in MDV increased by 25\% where it remained at elevated levels until 2012 (Obryk et al., 2018). Although mean summer air temperatures were cooling through this period by almost $1{ }^{\circ} \mathrm{C}$ (Doran et al., 2002b; Gooseff et al., 2017), the increase in solar energy more than compensated for sensible heat flux loss, at least for the sediment-covered surfaces with comparatively lower albedo, and for wetted sediment surfaces.

The triggering event was a short warm episode during mid-summer 2001-2002. A drainage wind event adiabatically warmed the atmosphere in the MDV to temperatures several degrees above freezing and the temperatures remained elevated for almost two weeks (Doran et al., 2008). During that period glacier ice rapidly melted, exposing sediment entombed in the subsurface; and streams and rivers flooded to a scale seen only twice before in the instrumented record since 1970 (Castendyk et al., 2016). During this period lake and pond levels rose rapidly. The fast, relatively warm stream flow; mechanically and thermally eroded the streambeds down to the ice-cemented permafrost boundary beneath the streambeds. Where massive ice was encountered, rapid erosion occurred followed by bank collapse and further erosion continued tunneling through the massive ice in some stream reaches (e.g., Garwood River). These processes set in motion a sequence of geomorphic changes that have continued for another decade.

We suggest that in the following years-under conditions of elevated solar radiation, constant summer air temperatures (Gooseff et al., 2017), and increased heat content of streams-landscape changes continued, partly responding to the flood event of 2001-2002 and partially from the elevated solar radiation. Insolation-driven glacial melt discharge was elevated despite constantly cool temperatures, contributing to continually increasing lake and pond levels.

\section{Conclusions}

Repeat lidar measurements of glacial, soil, stream, and lake surfaces in the McMurdo Dry Valleys show evidence of widespread ground subsidence, glacial ablation zone thinning and smoothing, and lake/pond level rise. The GPR observations indicate that soil subsidence is strongly associated with the presence of excess ground ice in the form of icecored moraines and tills. While not all locations of massive ground ice were found to be subject to subsidence, all notable subsidence observed is associated with massive ground ice. Thinning of glacier ablation zone surfaces along with thermokarst subsidence of soil surfaces suggest the possibility of widespread positive melting feedbacks, where melting of glacier surfaces and wetting of soil surfaces results in additional heat capture and delivery to ice, resulting in further darkening and melting of glacier surfaces and wetting and darkening of soil surfaces. While landscape changes are concentrated in locations with excess ground ice in the coastal thaw zone, changes to lakes and ponds are occurring across microclimate zones in the MDV. This expansion of thermokarst disruption and glacial change provides the physical backdrop for interpreting biotic change in the MDV, even in the stable upland zone. The widespread presence of massive ground ice indicates that many surfaces in the MDV will potentially undergo rapid (years to decades) subsidence of decimeters to decameters, resulting in changes to drainage, energy balance, and soil structure. Such potential for rapid and widespread change in coming years suggests that collection of topographic measurements on finer timescales than once per decade may be necessary to effectively manage the MDV natural laboratory and to prioritize melt-threatened sites for research before they are transformed by melting and subsidence.

\section{Acknowledgements}

This work was supported by the National Science Foundation Office of Polar Programs Antarctic Integrated Systems Science Program award ANT-1246342 to AGF, JSL, DVH, and MG. JT and CG were partially supported by NSF EAR/IF award \#1339015. Any opinions, findings, and conclusions or recommendations expressed in this material are those of the author(s) and do not necessarily reflect the views of the National Science Foundation (NSF). Thanks to Jay Dickson, Gonçalo Vieira, and two anonymous reviewers for their constructive reviews.

\section{Data availability}

Lidar data are available for download via the Polar Geospatial Center at http://data.pgc.umn.edu/elev/dem/ncalm/2014/las/ and via OpenTopography.

\section{Appendix A. Supplementary data}

Supplementary data to this article can be found online at https://doi. org/10.1016/j.geomorph.2018.09.012.

\section{References}

Adams, B.J., et al., 2006. Diversity and distribution of Victoria Land biota. Soil Biol. Biochem. 38, 3003-3018.

Arblaster, J.M., Meehl, G.A., 2006. Contributions of external forcings to southern annular mode trends. J. Clim. 19, 2896-2905

Arp, C.D., Whitman, M.S., Jones, B.M., Grosse, G., Gaglioti, B.V., Heim, K.C., 2015. Distribution and biophysical processes of beaded streams in Arctic permafrost landscapes. Biogeosciences 12, 29-47. https://doi.org/10.5194/bg-12-29-2015.

Barrett, J.E., Virginia, R.A., Wall, D.H., Doran, P.T., Fountain, A.G., Welch, K.A., Lyons, W.B., 2008. Persistent effects of a discrete warming event on a polar desert ecosystem. Glob. Chang. Biol. 14 (10), 2249-2261. 
Belshe, E.F., Schuur, E.A.G., Grosse, G., 2013. Quantification of upland thermokarst features with high resolution remote sensing. Environ. Res. Lett. 8. https://doi.org/10.1088/ 1748-9326/8/3/035017 (doi:10.1088-1748-9326-8-3-035016).

Bockheim, J.G., Campbell, I.B., McLeod, M., 2007. Permafrost distribution and active-layer depths in the McMurdo Dry Valleys, Antarctica. Permafr. Periglac. Process. 18, 217-227. https://doi.org/10.1002/ppp.588.

Bourke, M.C., Ewing, R.C., Finnegan, D., McGowan, H.A., 2009. Sand dune movement in the Victoria Valley, Antarctica. Geomorphology 109 (3-4), 148-160. https://doi.org/ 10.1016/j.geomorph.2009.02.028.

Braudrick, C.A., Dietrich, W.E., Leverich, G.T., Sklar, L.S., 2009. Experimental evidence for the conditions necessary to sustain meandering in coarse-bedded rivers. Proc. Natl. Acad. Sci. 106 (40), 16936-16941. https://doi.org/10.1073/pnas.0909417106.

Bristow, C.S., Augustinus, P.C., Wallis, I.C., Jol, H.M., Rhodes, E.J., 2010. Investigation of the age and migration of reversing dunes in Antarctica using GPR and OSL, with implications for GPR on Mars. Earth Planet. Sci. Lett. 289 (1-2), 30-42. https://doi.org/ 10.1016/j.epsl.2009.10.026.

Brook, E.J., Brown, E.T., Kurz, M.D., Ackert, R.P., Raisbeck, G.M., Yiou, F., 1995. Constraints on age, erosion, and uplift of Neogene glacial deposits in the Transantarctic Mountains determined from in situ cosmogenic 10Be and 26Al. Geology 23 (12), 1063-1066.

Campbell, I.B., Claridge, G., 2003. In: Phillips, M., Springman, S.M., Arenson, L.U. (Eds.), Thermokarst landforms in the Transantarctic Mountains region of Antarctica. Proceedings of the Eighth International Conference on Permafrost. Swets \& Zeltinger, Lisse, pp. 119-123.

Cary, S.C., McDonald, I.R., Barrett, J.E., Cowan, D.A., 2010. On the rocks: the microbiology of Antarctic cold desert soils. Nat. Rev. Microbiol. 8, 129-138.

Castendyk, D.N., Obryk, M.K., Leidman, S.Z., Gooseff, M., Hawes, I., 2016. Lake Vanda: a sentinel for climate change in the McMurdo Sound Region of Antarctica. Glob. Planet. Chang. 144, 213-227. https://doi.org/10.1016/j.gloplacha.2016.06.007.

Chapman, W.L., Walsh, J.E., 2007. A synthesis of Antarctic temperatures. J. Clim. 20, 4096-4117. https://doi.org/10.1175/JCLI4236.1.

Conovitz, P.A., McKnight, D.M., MacDonald, L.H., Fountain, A.G., House, H.R., 1998. Hydrologic processes influencing streamflow variation in Fryxell Basin, Antarctica. In: Priscu, J.C. (Ed.), Ecosystem Dynamics in a Polar Desert: The McMurdo Dry Valleys, Antarctica. American Geophysical Union, pp. 93-108.

Csatho, B.M., Schenk, T., Krabill, W.B., Wilson, T.J., Lyons, W.B., McKenzie, G., Hallam, C., Manizade, S., Paulsen, T., 2005. Airborne laser scanning for high-resolution mapping of Antarctica. Eos 86, 237-238.

Czudek, T., Demek, J., 1970. Thermokarst in Siberia and its influence on the development of lowland relief. Quat. Res. 1, 103-120. https://doi.org/10.1016/0033-5894(70) 90013-X.

Denton, G.H., Sugden, D.E., Marchant, D.R., Hall, B.L., Wilch, T.I., 1993. East Antarctic ice sheet sensitivity to Pliocene climatic change from a Dry Valleys perspective. Geogr. Ann. Ser. A Phys. Geogr. 75, 155-204.

Dickson, J.L., Levy, J.S., Head, J.W., 2015. Time-lapse imaging in polar environments. EOS Trans. Am. Geophys. Union 95, 1-2. https://doi.org/10.3189/002214310793146313.

Doran, P.T., McKay, C.P., Clow, G.D., Dana, G.L., Fountain, A.G., Nylen, T., Lyons, W.B., 2002 a. Valley floor climate observations from the McMurdo dry valleys, Antarctica, 1986-2000. J. Geophys. Res. 107. https://doi.org/10.1029/2001JD002045 (DOI: 10.1029-2001JD002045)

Doran, P.T., Priscu, J.C., Lyons, W.B., Walsh, J.E., Fountain, A.G., McKnight, D.M., Moorhead, D.L., Virginia, R.A., Wall, D.H., Clow, G.D., 2002b. Antarctic climate cooling and terrestrial ecosystem response. Nature 415, 517-520.

Doran, P.T., McKay, C.P., Fountain, A.G., Nylen, T., McKnight, D.M., Jaros, C., Barrett, J.E., 2008. Hydrologic response to extreme warm and cold summers in the McMurdo Dry Valleys, East Antarctica. Antarct. Sci. 20 (5), 499-509.

Eveland, J., Gooseff, M.N., Lampkin, D.J., Barrett, J.E., Takacs-Vesbach, C., 2013. Spatial and temporal patterns of snow accumulation and aerial ablation across the McMurdo Dry Valleys, Antarctica. Hydrol. Process. 22, 2864-2875. https://doi.org/10.1002/hyp.9407.

Farquharson, L.M., Mann, D.H., Grosse, G., Jones, B.M., Romanovsky, V.E., 2016. Spatial distribution of thermokarst terrain in Arctic Alaska. Geomorphology 273, 116-133. https://doi.org/10.1016/j.geomorph.2016.08.007.

Fernandez-Diaz, J., Carter, W., Glennie, C., Shrestha, R., Pan, Z., Ekhtari, N., Singhania, A., Hauser, D., Sartori, M., 2016. Capability assessment and performance metrics for the Titan multispectral mapping lidar. Remote Sens. 8. https://doi.org/10.3390/rs8110936.

Fortier, D., Allard, M., Shur, Y., 2007. Observation of rapid drainage system development by thermal erosion of ice wedges on Bylot Island, Canadian Arctic Archipelago. Permafr. Periglac. Process. 18, 229-243. https://doi.org/10.1002/ppp.595.

Fountain, A.G., Lyons, W.B., Burkins, M.B., Dana, G.L., Doran, P.T., Lewis, K.J., McKnight, D.M., Moorhead, D.L., Parsons, A.N., Priscu, J.C., 1999. Physical controls on the Taylor Valley ecosystem, Antarctica. Bioscience 49, 961-971.

Fountain, A.G., Nylen, T.H., Monaghan, A., Basagic, H.J., Bromwich, D., 2009. Snow in the McMurdo Dry Valleys, Antarctica. Int. J. Climatol. 30, 633-642. https://doi.org/ 10.1002/joc.1933.

Fountain, A.G., Levy, J.S., Gooseff, M.N., Van Horn, D., 2014. The McMurdo Dry Valleys: a landscape on the threshold of change. Geomorphology 225, 25-35. https://doi.org/ 10.1016/j.geomorph.2014.03.044.

Fountain, A.G., Basagic, H.J., Niebuhr, S., 2016a. Glaciers in equilibrium, McMurdo Dry Valleys, Antarctica. J. Glaciol. 62, 976-989. https://doi.org/10.1017/jog.2016.86.

Fountain, A.G., Saba, G., Adams, B., Doran, P., Fraser, W., Gooseff, M., et al., 2016b. The impact of a large-scale climate event on Antarctic ecosystem processes. BioScience 66 (10), 848-863. https://doi.org/10.1093/biosci/biw110.

Fountain, A.G., Fernandez-Diaz, J.C., Obryk, M., Levy, J., Gooseff, M., Van Horn, D.J., Morin, P., Shrestha, R., 2017. High-resolution elevation mapping of the McMurdo Dry Valleys, Antarctica, and surrounding regions. Earth Syst. Sci. Data 9, 435-443. https:// doi.org/10.5194/essd-9-435-2017.
French, H., Shur, Y., 2010. The principles of cryostratigraphy. Earth Sci. Rev. 101, 190-206. https://doi.org/10.1016/j.earscirev.2010.04.002.

Ganti, V., Von Hagke, C., Scherler, D., Lamb, M.P., Fischer, W.W., Avouac, J.P., 2016. Time scale bias in erosion rates of glaciated landscapes. Sci. Adv. 2 (10), e1600204. https://doi.org/10.1126/sciadv.1600204.

Gillies, J.A., Nickling, W.G., Tilson, M., 2013. Frequency, magnitude, and characteristics of aeolian sediment transport: McMurdo Dry Valleys, Antarctica. J. Geophys. Res. Earth Surf. 118, 461-479. https://doi.org/10.1002/jgrf.20007.

Gooseff, M.N., McKnight, D.M., Doran, P., Fountain, A.G., Lyons, W.B., 2011. Hydrological connectivity of the landscape of the McMurdo Dry Valleys, Antarctica. Geogr. Compass 5 (9), 666-681.

Gooseff, M.N., Van Horn, D., Sudman, Z., McKnight, D.M., Welch, K.A., Lyons, W.B., 2016 Stream biogeochemical and suspended sediment responses to permafrost degradation in stream banks in Taylor Valley, Antarctica. Biogeosciences 13 (6), 1723-1732. https://doi.org/10.5194/bg-13-1723-2016.

Gooseff, M.N., Barrett, J.E., Adams, B.J., Doran, P.T., Fountain, A.G., Lyons, W.B., McKnight, D.M., Priscu, J.C., Sokol, E.R., Takacs-Vesbach, C., Vandegehuchte, M.L., Virginia, R.A., Wall, D.H., 2017. Decadal ecosystem response to an anomalous melt season in a polar desert in Antarctica. Nat. Ecol. Evol. 1, 1334-1338. https://doi.org/10.1038/ s41559-017-0253-0.

Hagedorn, B., Sletten, R.S., Hallet, B., 2007. Sublimation and ice condensation in hyperarid soils: modeling results using field data from Victoria Valley, Antarctica. J. Geophys. Res. 112, F03017. https://doi.org/10.1029/2006JF000580.

Hagedorn, B., Sletten, R.S., Hallet, B., McTigue, D.F., Steig, E.J., 2010. Ground ice recharge via brine transport in frozen soils of Victoria Valley, Antarctica: Insights from modeling $\delta 180$ and $\delta$ D profiles. Geochim. Cosmochim. Acta 74 (2), 435-448.

Hall, B.L., Denton, G.H., 2000. Radiocarbon chronology of Ross Sea drift, eastern Taylor Valley, Antarctica: evidence for a grounded ice sheet in the Ross Sea at the last glacial maximum. Geogr. Ann. Ser. B 82, 305-336.

Hall, B.L., Denton, G.H., Hendy, C.H., 2000. Evidence from Taylor Valley for a grounded ice sheet in the Ross Sea, Antarctica. Geogr. Ann. Ser. B 82A, 275-303.

Hall, B.L., Denton, G.H., Heath, S.L., Jackson, M.S., Koffman, T.N.B., 2015. Accumulation and marine forcing of ice dynamics in the western Ross Sea during the last deglaciation. Nat. Geosci. 8, 625-628. https://doi.org/10.1038/ngeo2478.

Harrison, W.D., Elsberg, D.H., Echelmeyer, K.A., Krimmel, R.M., 2001. On the characterization of glacier response by a single time-scale. J. Glaciol. 47 (159), 659-664.

Healy, T.R., 1975. Thermokarst-a mechanism of de-icing ice-cored moraines. Boreas 4, 19-23.

Higgins, S.M., Denton, G.H., Hendy, C.H., 2000a. Glacial geomorphology of Bonney drift, Taylor Valley, Antarctica. Geogr. Ann. Ser. A Phys. Geogr. 82A, 365-389.

Higgins, S.M., Hendy, C.H., Denton, G.H., 2000b. Geochronology of Bonney drift, Taylor Valley, Antarctica: evidence for interglacial expansions of Taylor Glacier. Geogr Ann. Ser. A Phys. Geogr. 82A, 391-409.

Hoffman, M.J., Fountain, A.G., Liston, G.E., 2016. Distributed modeling of ablation (1996-2011) and climate sensitivity on the glaciers of Taylor Valley, Antarctica. J. Glaciol. 62, 215-229. https://doi.org/10.1017/jog.2015.2.

Irvine-Fynn, T.D.L., Barrand, N.E., Porter, P.R., Hodson, A.J., Murray, T., 2011. Recent HighArctic glacial sediment redistribution: a process perspective using airborne lidar. Geomorphology 125, 27-39. https://doi.org/10.1016/j.geomorph.2010.08.012.

Jóhannesson, T., Raymond, C., Waddington, E.D., 1989. Time-scale for adjustment of glaciers to changes in mass balance. J. Glaciol. 35 (121), 355-369.

Jol, H.M., 2009. Ground Penetrating Radar Theory and Applications. Elsevier Science, Amsterdam 9780444533487 (544p.).

Jorgenson, M.T., Shur, Y., 2007. Evolution of lakes and basins in northern Alaska and discussion of the thaw lake cycle. J. Geophys. Res. 112, 78-12. https://doi.org/10.1029/ 2006JF000531.

Jorgenson, M.T., Shur, Y.L., Pullman, E.R., 2006. Abrupt increase in permafrost degradation in Arctic Alaska. Geophys. Res. Lett. 33, 180-184. https://doi.org/10.1029/ 2005 GL024960.

Kanevskiy, M., Shur, Y., Strauss, J., Jorgenson, T., Fortier, D., Stephani, E., Vasiliev, A., 2016. Patterns and rates of riverbank erosion involving ice-rich permafrost (yedoma) in northern Alaska. Geomorphology 253, 370-384. https://doi.org/10.1016/j.geomorph.2015.10.023.

Kowalewski, D.E., Marchant, D.R., Levy, J.S., Head, J.W., 2006. Quantifying low rates of summertime sublimation for buried glacier ice in Beacon Valley, Antarctica. Antarct. Sci. 18. https://doi.org/10.1017/S0954102006000460.

Kowalewski, D.E., Marchant, D.R., Head III, J.W., Jackson, D.W., 2011a. A 2D model for characterising first-order variability in sublimation of buried glacier ice, Antarctica: assessing the influence of polygon troughs, desert pavements and shallow subsurface salts. Permafr. Periglac. Process. 23, 1-14. https://doi.org/10.1002/ppp.731.

Kowalewski, D.E., Marchant, D.R., Swanger, K.M., James W Head, I., 2011b. Modeling vapor diffusion within cold and dry supraglacial tills of Antarctica: Implications for the preservation of ancient ice. Geomorphology 126, 159-173. https://doi.org/ 10.1016/j.geomorph.2010.11.001.

Lacelle, D., Davila, A.F., Fisher, D., Pollard, W.H., DeWitt, R., Heldmann, J., Marinova, M.M., McKay, C.P., 2013. Excess ground ice of condensation-diffusion origin in University Valley, Dry Valleys of Antarctica: evidence from isotope geochemistry and numerical modeling. Geochim. Cosmochim. Acta 120, 280-297. https://doi.org/10.1016/j. gca.2013.06.032

Levy, J., 2012. How big are the McMurdo Dry Valleys? Estimating ice-free area using Landsat image data. Antarct. Sci. 25, 119-120. https://doi.org/10.1017/S0954102012000727.

Levy, J.S., Schmidt, L.S., 2016. Thermal properties of Antarctic soils: wetting controls subsurface thermal state. Antarct. Sci. 28, 361-370.

Levy, J.S., Fountain, A.G., Gooseff, M.N., Welch, K.A., Lyons, W.B., 2011. Water tracks and permafrost in Taylor Valley, Antarctica: extensive and shallow groundwater connectivity in a cold desert ecosystem. Geol. Soc. Am. Bull. 123, 2295-2311. https://doi.org/ 10.1130/B30436.1. 
Levy, J.S., Fountain, A.G., Dickson, J.L., Head, J.W., Okal, M., Marchant, D.R., Watters, J. 2013a. Accelerated formation of thermokarst in Garwood Valley, Antarctica. Sci. Rep. 3 (DOI:10.1038-srep02269)

Levy, J.S., Fountain, A.G., O'Connor, J.E., Welch, K.A., Lyons, W.B., 2013b. Garwood Valley, Antarctica: a new record of last glacial maximum to Holocene glacio-fluvial processes in the McMurdo Dry Valleys. Geol. Soc. Am. Bull. 125, 1484-1502.

Mader, G.L., 1996. Kinematic and rapid static (KARS) GPS positioning: techniques and recent experiences. GPS Trends in Precise Terrestrial, Airborne, and Spaceborne Applications. Springer, Berlin, pp. 170-174.

Marchant, D.R., Head III, J.W., 2007. Antarctic dry valleys: microclimate zonation, variable geomorphic processes, and implications for assessing climate change on Mars. Icarus 192, 187-222. https://doi.org/10.1016/j.icarus.2007.06.018.

Marchant, D.R., Denton, G.H., Sugden, D.E., Swisher III, C.C., 1993a. Miocene glacial stratigraphy and landscape evolution of the Western Asgard Range, Antarctica. Geogr. Ann. Ser. B 75, 303-332. https://doi.org/10.2307/521205.

Marchant, D.R., Denton, G.H., Swisher III, C.C., 1993b. Miocene-Pliocene-Pleistocene glacial history of Arena Valley, Quartermain Mountains, Antarctica. Geogr. Ann. Ser. A Phys. Geogr. 75, 269-302.

Marchant, D.R., Lewis, A.R., Phillips, W.M., Moore, E.J., Souchez, R.A., Denton, G.H., Sugden, D.E., Potter, N., Landis, G.P., 2002. Formation of patterned ground and sublimation til over Miocene glacier ice in Beacon Valley, southern Victoria Land, Antarctica. Geol. Soc. Am. Bull. 114, 718-730.

Marinova, M.M., McKay, C.P., Pollard, W.H., Heldmann, J.L., Davila, A.F., Andersen, D.T., Jackson, W.A., Lacelle, D., Paulsen, G., Zacny, K., 2013. Distribution of depth to icecemented soils in the high-elevation Quartermain Mountains, McMurdo Dry Valleys, Antarctica. Antarct. Sci. 25, 575-582. https://doi.org/10.1017/S095410201200123X

Martin, C.F., Thomas, R.H., Krabill, W.B., Manizade, S.S., 2005. ICESat range and mounting bias estimation over precisely-surveyed terrain. Geophys. Res. Lett. 32. https://doi. org/10.1029/2005GL023800.

Mölg, T., 2004. Ablation and associated energy balance of a horizontal glacier surface on Kilimanjaro. J. Geophys. Res. 109, 159-14. https://doi.org/10.1029/2003JD004338.

Monaghan, A.J., Bromwich, D.H., Powers, J.G., 2005. The climate of the McMurdo, Antarctica, region as represented by one year of forecasts from the Antarctic Mesoscale Prediction System. J. Clim. 18, 1174-1189. https://doi.org/10.1175/JCLI3336.1.

Morfitt, R., Barsi, J., Levy, R., Markham, B., Micijevic, E., Ong, L., Scaramuzza, P., Vanderwerff, K., 2015. Landsat-8 operational land imager (OLI) radiometric performance on-orbit. Remote Sens. 7, 2208-2237. https://doi.org/10.3390/rs70202208.

Ng, F., Hallet, B., Sletten, R.S., Stone, J.O., 2005. Fast-growing till over ancient ice in Beacon Valley, Antarctica. Geology 33, 121. https://doi.org/10.1130/G21064.1.

Nylen, T.H., Fountain, A.G., 2004. Climatology of katabatic winds in the McMurdo dry valleys, southern Victoria Land, Antarctica. J. Geophys. Res. 109 (D3), D03114. https:// doi.org/10.1029/2003JD003937.

Nylen, T., White, S., 2007. Online Precise Point Position Using the National Resources Canada Canadian Spatial Reference System (CSRS-PPP). UNAVCO Report. https:// www.unavco.org/projects/project-support/polar/support/PPP.pdf (8p.).

Obryk, M.K., Doran, P.T., Hicks, J.A., McKay, C.P., Priscu, J.C., 2016a. Modeling the thicknes of perennial ice covers on stratified lakes of the Taylor Valley, Antarctica. J. Glaciol. 62 (235), 825-834. https://doi.org/10.1017/jog.2016.69.

Obryk, M.K., Doran, P.T., Friedlaender, A.S., Gooseff, M.N., Li, W., Morgan-Kiss, R.M., et al., 2016b. Responses of Antarctic marine and freshwater ecosystems to changing ice conditions. Bioscience 66 (10), 864-879. https://doi.org/10.1093/biosci/biw109.

Obryk, M.K., Fountain, A.G., Doran, P.T., Lyons, W.B., Eastman, R., 2018. Drivers of solar radiation variability in the McMurdo Dry Valleys, Antarctica. Sci. Rep. 8 (1), 5002.
Priscu, J.C. Fritsen, C.H. Adams, E. E Giovannoni, S.J., Paerl, H.W., McKay, C.P., Doran, P.T. Gordon, D.A., Lanoil, B.D., Pinckney, J.L., 1998. Perennial Antarctic lake ice: an oasis for life in a polar desert. Science 280, 2095-2098.

Rippin, D.M., Pomfret, A., King, N., 2015. High resolution mapping of supra-glacial drainage pathways reveals link between micro-channel drainage density, surface roughness and surface reflectance. Earth Surf. Process. Landf. 40, 1279-1290. https://doi. org/10.1002/esp.3719.

Roe, G.H., O'Neal, M.A., 2009. The response of glaciers to intrinsic climate variability: observations and models of late-Holocene variations in the Pacific Northwest. J. Glaciol. 55 (193), 839-854.

Schenk, T., Csatho, B.M., Ahn, Y., Yoon, T., Shin, W.S., 2004. DEM generation from the Antarctic Lidar data: site report. US Geological Survey.

Schmidt, L.M., Levy, J.S., 2017. Hydraulic conductivity of active layer soils in the McMurdo Dry Valleys, Antarctica: Geological legacy controls modern hillslope connectivity. Geomorphology 283, 61-71. https://doi.org/10.1016/j.geomorph.2017.01.038.

Shindell, D.T., Schmidt, G.A., 2004. Southern Hemisphere climate response to ozone changes and greenhouse gas increases. Geophys. Res. Lett. 31. https://doi.org/ 10.1029/2004GL020724.

Shur, Y.L., Jorgenson, M.T., 2007. Patterns of permafrost formation and degradation in relation to climate and ecosystems. Permafr. Periglac. Process. 18 (1), 7-19. https://doi. org/10.1002/ppp.582.

Stockton, W.L., 1983. Submarine ice cliffs on the west side of McMurdo Sound, Antarctica. J. Glaciol. 29, 272-282.

Stockton, W.L., DeLaca, T.E., Deniro, M.J., 1984. Stable isotope analysis of a submarine ice cliff at Explorers Cove, McMurdo Sound, Antarctica. J. Glaciol. 30, 112-115.

Strauss, J., Fedorov, A.N., Fortier, D., Froese, D., Fuchs, M., Grosse, G., Günther, F., Harden, J., Hugelius, G., Kanevskiy, M., Kholodov, A.L., Kunitsky, V.V., Laboor, S., LapointeElmrabti, L., Rivkina, E., Robinson, J., Schirrmeister, L., Shmelev, D., Shur, Y., Spektor, V.V. Ulrich, M. Veremeeva, A., Walter Anthony, K.M., Zimov, S., 2016. Ice-Rich Yedoma Permafrost: Circum-Arctic Distribution and Thickness Synthesis. EPIC3Annual Meeting of the "Working Group Permafrost". German Society for Polar Research, Hamburg, Germany (2016-01-22-2016-01-24).

Stuiver, M., Denton, G.H., Hughes, T.J., Fastook, J.L., 1981. History of the marine ice sheet in West Antarctica during the last glaciation: a working hypothesis. In: Denton, G.H., Hughes, T.J. (Eds.), The Last Great Ice Sheets. John Wiley \& Sons, New York, NY, pp. 319-362.

Sudman, Z., Gooseff, M.N., Fountain, A.G., Levy, J.S., Obryk, M.K., Van Horn, D., 2017. Impacts of permafrost degradation on a stream in Taylor Valley, Antarctica. Geomorphology 285, 205-213. https://doi.org/10.1016/j.geomorph.2017.02.009.

Sugden, D.E., Marchant, D.R., Potter Jr., N., Souchez, Roland, Denton, G.H., Swisher, C.C., Tison, J.-L., 1995. Miocene glacier ice in Beacon Valley, Antarctica. Nature 376, 412-416.

Swanger, K.M., 2017. Buried ice in Kennar Valley: a late Pleistocene remnant of Taylor Glacier. Antarct. Sci. 29 (3), 239-251.

Swanger, K.M., Marchant, D.R., 2007. Sensitivity of ice-cemented Antarctic soils to greenhouse-induced thawing: are terrestrial archives at risk? Earth Planet. Sci. Lett. 259, 347-359. https://doi.org/10.1016/j.epsl.2007.04.046.

Telling, J., Glennie, C., Fountain, A., Finnegan, D., 2017. Analyzing glacier surface motion using lidar data. Remote Sens. 9, 283-12. https://doi.org/10.3390/rs9030283.

Ugolini, F.C., Bockheim, J.G., 2008. Antarctic soils and soil formation in a changing environment: a review. Geoderma 144, 1-8. https://doi.org/10.1016/j.geoderma.2007.10.005. 